\title{
Fen Bilgisi Öğretmeni Adaylarının Bazı Kimya Konularında Akıl Yürütmelerinin İncelenmesi
}

\author{
Erol Asiltürk*, Gülay İlhan**
}

Makale Geliş Tarihi: 31.10 .2018

Makale Kabul Tarihi:25.12.2019

DOI: $10.35675 /$ befdergi.477156

$\ddot{O} z$

Bu çalışmanın amacı, fen bilgisi öğretmeni adaylarının kimyasal reaksiyonlar, kinetik molekül teorisi, faz dengeleri, termokimya ve termodinamik konularındaki akıl yürütmelerini incelemektir. Bu sebeple araştırma kesitsel tarama türündedir. Çalışmaya Fırat Üniversitesi Ĕ̆itim Fakültesi Fen Bilgisi Ĕgitimi programına kayıtlı 210 (180 Bayan, 30 Erkek) öğrenci katılmıştır. Çalışmada Cloonan ve Hutchinson (2011) tarafindan geliştirilmiş olan Kimya Konularl Akıl Yürütme Testi'ninkimyasal reaksiyonlar, kinetik moleküler teorisi, faz dengeleri, termokimya ve termodinamik bölümleri veri toplama aracı olarak kullanılmıştır. Çalışma sonucunda fen bilgisi ögretmeni adaylarının çoğunun bu çalışmada incelenen kimya konulart ile ilgili olarak doğru olmayan akl yürütmelere sahip olduklart tespit edilmistir. Çalışmada katılımcıların seçilen konularla ilgili akıl yürütmelerinin düşük olduğu ve bu çalışma grubu için test maddelerinin zor olduğu sonucuna ulaşılmıştır. Araştırmada elde edilen bulgular çerçevesinde ileride bu alanda çalışmak isteyen araştırmacılara çalışma kapsamına dâhil edilen kimya konularına ilişkin akıl yürütmeleri ile ilgili birtakım önerilerde bulunulmuştur.

Anahtar Kelimeler: Akıl yürütme, faz dengeleri, kimyasal reaksiyonlar, kinetik molekül teorisi, termodinamik, termokimya.

\section{Investigation of Reasoning the Pre-service Science Teachers' at Some Chemistry Topics}

\begin{abstract}
The aim of this study is to investigate the reasoning of science teacher candidates on chemical reactions, kinetic molecule theory, phase equilibrium, thermochemistry and thermodynamics. Therefore, the study is of cross-sectional screening. 210 (180 Female, 30 Male) students enrolled in the Science Teaching program of the Faculty of Education of Firat University participated in the study. In this study, thechemical reactions, kinetic molecule theory, phase equilibrium, thermochemistry and thermodynamic sections of the Chemistry Subjects Reasoning Test developed by Cloonan and Hutchinson (2011) were used as data collection tools. As a result of the study, it was determined that most of the science teacher candidates had inaccurate reasoning about the chemistry subjects studied in this study. In the study, it was found that the participants' reasoning about selected subjects was low and the test items for this study group were difficult. Within the framework of the findings of the study, some suggestions were made to the researchers who wish to work in this field in the future about their reasoning about chemistry subjects included in the study.
\end{abstract}

\footnotetext{
* Firat Üniversitesi, Eğitim Fakültesi, Matematik ve Fen Bilimleri Eğitimi Bölümü, Elazı̆̆g, Türkiye, ecil@firat.edu.tr, ORCID: 0000-0001-8126-7812

${ }^{* *}$ Milli Eğitim Bakanlığı, Raşit Yüksel Anadolu İmam Hatip Lisesi, Tunceli, Türkiye, tam.kare@gmail.com, ORCID: 0000-0001-9439-217X

Kaynak Gösterme: Asiltürk, E. ve İlhan, G. (2019). Fen bilgisi öğretmeni adaylarının bazı kimya konularında akıl yürütmelerinin incelenmesi. Bayburt Eğitim Fakültesi Dergisi, 14(28), 391-417. https://doi.org/10.35675/befdergi.477156
} 
Keywords: Reasoning, phase equilibrium, chemical reactions, kinetic molecule theory, thermodynamic, thermochemistry.

\section{Giriş}

Akıl yürütme kavramının ortaya çıkışı ilk çağlara dayanmaktadır. Bu süreçte birçok bilim insanı bu kavramı doğrudan ya da dolaylı olarak dile getirmiştir. Bilinen yazılı kaynaklara göre akıl yürütme antik yunan tarihinden bu yana çalışılan bir konudur. Aristotale, tüm canlılar içerisinde sadece insanların böyle bir yeteneğe sahip olduklarını ve mantıklı düşünebileceklerini belirtmiştir (Oaksford, 2005). Bilişsel gelişim içerisinde yer alan akıl yürütmeleri ile ilgili olarak akıl yürütmenin insanın uyum yetileri arasında en zorunun olduğu ve insanın tecrübelerini birleştirerek yeni düzenlemelere ulaştığı yapıcı bir düşünme tarzı olduğu belirtilmiştir. Bu gelişim sürecinde akıl yürütme kavramı tanımlanmaya çalışılmıştır. Akıl yürütme, insanların bilgiyi aldığı ve verilere göre bir çıkarımda bulunduğu bilişsel bir süreç olarak da tarif edilebilir (Kurtz, Gentner ve Gunn, 1999). Hipotezin kurulması ve denenmesi sürecinde akıl yürütme kavramı önemli rol oynamaktadır. Bir hipotezin doğru olup olmadığını ortaya çıkarmak için ondan mantıki akıl yürütme yoluyla gözlenmesi mümkün birtakım sonuçlar çıkarmak gerekir. Hipotezin kurulması noktasından hareketle akıl yürütme; bütün etmenleri dikkate alarak düşünüp akılcı bir sonuca ulaşma süreci olarak da düşünülebilir. Öğretim sürecinde veya günlük hayatta bir konuda akıl yürütebilen biri; yeterli düzeyde bilgi sahibidir, yeni karşılaştığ durumu tüm boyutlarıyla inceler, keşfeder, mantıklı tahminlerde, varsayımlarda bulunur, düşüncelerini gerekçelendirir, bazı sonuçlara ulaşır, ulaştığ 1 sonucu açıklayabilir ve savunabilir (Umay, 2003). Akıl yürütme kavramı NAEYC (National Association for the Education of Young Children) tarafından çocukların öğrenmeleri gereken bir beceri olarak savunulmaktadır. Bu kuruluş akıl yürütmenin çocuklara erken yaşlardan itibaren verilmesi gerektiğini savunmuştur (Storey, 2004).

Bilimin gelişim süreciyle beraber akıl yürütme kavramı ortaya çıkmış ve her geçen gün üzerinde çalışmalar yapılan bir kavram haline gelmiştir. Bu gelişim sürecinde akıl yürütme kavramı birçok bilim adamı tarafından tanımlanmaya çalışılmıştır. Umay’ın (2003) tanımına göre akıl yürütme; "Bütün etmenleri dikkate alarak düşünüp akılcı bir sonuca ulaşma süreci”; düşünme süreci ise "olaylardan anlam çıkartıp koşulları kendine uygun olarak yeniden düzenleyebilme yeteneği" şeklindedir (Umay, 2003). Fen bilgisi öğretmeni adaylarının kimya konularını anlamaları üzerine literatürde çok sayıda çalışma mevcuttur. Örneğin asitler ve bazlar, maddenin yapısı, faz dengeleri, elektrokimya ve çözelti kimyası konularını fen bilgisi öğretmeni adaylarının anlama düzeyleri değişik araştırma grupları tarafindan detaylı bir şekilde incelenmiştir (Alkan, ve Geban, 2006; Ayas, ve Coll, 2007; Azizoğlu, Özkaya, Uce ve Sahin, 2003; Haidar, 1997; Sandur, Ozbayrak, ve Uyulgan, 2011; Valanides, 2000; Çalık, Ayas ve Coll, 2010). Bu çalışmalarda genel olarak fen bilgisi öğretmeni adaylarının bahsedilen kimya konularını anlama düzeylerinin düşük olduğu sonucuna ulaşılmıştır. 
Araştırmacıların yaptıkları literatür taraması kapsamında ülkemizde diğer akıl yürütme türleri ile ilgili çalışmalara rastlanmasına rağmen kimya konularında akıl yürütme ile ilgili doğrudan ilişkili olan herhangi bir çalışmaya rastlanmamıştır. Sadece birkaç araştırmacı bu alanla ilgili dolaylı yönden araştırma yapmıştır. Aladağ ve Artut (2012) yapmış oldukları çalışmalarında ilköğretim öğrencilerinin orantısal akıl yürütmeleri ile gerçekçi problem çözme becerilerini araştırmışlardır. Çalışma bulguları neticesinde öğrencilerin orantısal akıl yürütmede başarılı olduklarını ve sınıf düzeylerinin artmasıyla problem çözebilme becerilerinin orantılı bir şekilde arttığını tespit etmişlerdir. Ayrıca öğrencilerin orantısal akıl yürütmeleri ile problem çözme becerileri arasında da anlamlı bir ilişki bulunmuştur. Tümkaya (2011) çalışmasında fen bilimleri öğrencilerinin eleştirel düşünme eğilimleri ve öğrenme stillerini incelemiştir. Araştırmada fen bilimleri öğrencilerinin en yüksek puanı "analitiklik" alt ölçeğinden aldıkları, sorun çıkabilecek durumlara karşı dikkatli olma ve zor problemler karşısında bile akıl yürütme ve nesnel kanıtları kullanma özelliğine sahip oldukları tespit edilmiştir. Ayrıca çalışmada bu durumun, fen bilimleri bölümlerindeki derslerin içeriğinin neden-sonuç ilişkisi kurulmasına, nesnel, problem çözmeye ve akıl yürütmeye dayalı olmasından kaynaklandığı ifade edilmiştir. Çelik ve Özdemir (2011) yapmış oldukları çalışmalarında ilköğretim 7. ve 8. sınıf öğrencilerinin akıl yürütmeleri ile oran-orantı problem kurma becerileri arasındaki ilişkiyi araştırmışlardır. Araştırmacılar, analiz ettikleri bulgular çerçevesinde akıl yürütmeleri ile oran-orantı problemi kurma becerilerinin birbiriyle bağlantılı olduğunu tespit etmişlerdir. Sandur, Öz bayrak ve Uyulgan, (2011)'de asit ve baz kavramları üzerine bir çalışma yapmıştır. Haidar, (1997) faz dengeleri üzerine yapmış olduğu çalışmasında akıl yürütme kavramına çok az değinmiştir. Azizoğlu, Alkan ve Geban (2006)'da elektrokimya alanında yapmış olduğu çalışmada akıl yürütme kavramının önemli olduğundan bahsetmiştir. Özkaya, Uce ve Şahin, (2003) kimyasal çözümleme alanında yapmış olduğu çalışmada öğrencilerin akıl yürütmeleri gerektiğini belirtmiştir. Yine Çalık, Ayas ve Coll (2010) kimya alanında yapmış oldukları çalışmada akıl yürütme kavramına yüzeysel bir şekilde değinmişlerdir. Çetin, Erdurhan ve Kaya (2010) yapmış oldukları çalışmada, bilimde argümantasyon ve alana özel akıl yürütme yollarını özellikle kimya öğretmeni adaylarına özgü kalıplara odaklanarak incelemek için, bu iki ayrı alan yazını bir araya getirmeyi amaçlamıştır. Öğrencinin sodyum elementinin sembolünün $\mathrm{Na}$ olduğunu öğrenmesi bilgi düzeyinde bir öğrenme olmasına rağmen, bu elementin bileşiklerini sembollerle gösterirken hep $\mathrm{Na}$ sembolünü kullanması tümdengelimdir. Kavrama, uygulama, analiz, sentez ve değerlendirme seviyelerindeki öğrenmelerde tümevarım, analojik ve diyalektik akıl yürütme süreçleri de kullanılabilmektedir (Tekin ve Ayas, 2002). Kimya konularında akıl yürütme; kimya bilgilerini anlamada ve açıklamada, kimyayla ilgili teorik, istatistiksel ve hipotezlerin nedenini anlamada gerekli olan bilişsel beceriler olarak tanımlanabilir. Apaydın ve Taş (2010) çalışmalarında farklı etkinlik tiplerinin öğretmen adaylarının akıl yürütme ve düşünme becerileri üzerindeki etkisini incelemiştir. Araştırma sonuçlarına göre, etkinlik tipinin öğrencilerin akıl 
yürütmeleri üzerinde etkili olduğu belirlenmiştir. Pehlivan (2010) öğretmen adaylarının öğrenme stilleri ve öğretmenlik mesleğine yönelik tutumlarını araştırmıştır. Araştırmacı elde ettiği bulgular neticesinde ayrıştıran öğrenme stiline sahip bireylerin zihinsel analiz, tümden gelimci akıl yürütme ve sistematik planlama özelliklerine sahip olduğunu tespit etmiş̧ir. Tok (2008) çalışmasında yansıtıcı düşünme ve akıl yürütme etkinliklerinin öğrencilerin akademik başarıları ve tutumlarına etkisini incelemiştir. Çalışma bulguları, yansıtıcı düşünme ve akıl yürütme etkinliklerinin öğrencilerin fen bilgisi akademik başarılarını artırdığını ve tutumlarını olumlu yönde etkilediğini göstermiştir.

Yurt dışında da kimya konularında akıl yürütme ile ilgili birkaç çalışma bulunmaktadır. Banda (2012)' de yapmış olduğu çalışmada lise öğrencilerinin kimya konularında akıl yürütmelerini tespit etmeye çalışmıştır. Yurt dışında yapılan diğer çalışmalarda bireylerin kimya konularındaki akıl yürütmelerini belirlemek için; Madde Tepkime Teorisi(ITR:Item Response Theory), Bir Parametreli Lojistik Model (1PL:One Parameter Logistic Model), İki Parametreli Lojistik Model(2PL:Two Parameter Logistic Model) ve Üç Parametreli Lojistik Model(3PL:Three Parameter Logistic Model) şeklinde modeller kullanılmıştır (Furr ve Bacharach, 2008). Bu model çalışmaları doğrultusunda bilim araştırmacıları kimya konularındaki yeteneklerini ölçebilmek için Kimya konularında akıl yürütme testi [Chemical Concept Reasoning Test (CCRT)] geliştirmişlerdir (Cloonan ve Hutchinson, 2011). Cavallo (1996) yapmış olduğu çalışmada öğrencilerin kimya konularında akıl yürütmelerini araştırmıştır. McClary ve Talanquer (2010) çalışmalarında öğrencilerin akıl yürütme stratejilerinin karakterizasyonu, anlamlı öğrenmeyi teşvik eden öğretim stratejilerinin geliştirilmesinde merkezi bir öneme sahip olduğunu dile getirmişlerdir. Özellikle, öğrencilerin bilişsel yükünü azaltmak için kullandıkları kısayol akıl yürütme prosedürlerinin (sezgisel) belirlenmesinin, daha analitik düşünme biçimlerinin geliştirilmesini kolaylaştıracak stratejiler geliştirmemize yardımcı olabileceği ifade edilmiştir. Elde edilen sonuçlar, birçok araştırmacının, kararlarının çoğunu yapmak için şu sezgisel yöntemlerden bir veya daha fazlasına yoğunlaştığını göstermiştir: İndirgeme, temsil gücü ve sözcükbilim. Her bir görevde yer alan maddeler hakkında yapısal bilgilere ulaşmak için görsel erişimi olmasına rağmen, birçok öğrenci kararlarını vermek için kavramsal özelliklerine ve bilgilerine güvenmiştir. Bununla birlikte, görevlerin belirli özellikleri, farklı şekillerde sezgisel akıl yürütmeyi tetiklemiş görünmektedir. Sezgisel kullanım, öğrencilerin sıralama görevlerinin bazı bileşenlerini basitleştirmelerine ve doğru yanıtlar üretmesine izin verse de, genellikle onları yoldan çıkarmıştır. Elde edilen sonuçlar, üniversitedeki kimya öğrencilerinin düşüncelerini gözlemlemek ve farklı bağlamlarda sezgisel akıl yürütme stratejilerine karşı analitik yaklaşımların etkinliğini değerlendirmek için yeteneklerini açıkça geliştiren öğretim müdahalelerine duyulan ihtiyacı ortaya koymaktadır. Kraft, Strickland ve Bhattacharyya (2010) öğrencilerin çok değişkenli problemlere nasıl yaklaştıklarını anlamak için, organik kimya yüksek lisans öğrencilerinin mekanizma görevlerinden algıladıkları ipuçları ve bu işaretlerin neden olduğu muhakeme 
süreçleri üzerine bir çalışma yapılmıştır. Çalışmada elde edilen bulgular, öğrencilerin görevlerde kullanılan sunumların yorumlarını düşük düzeyde ortaya koyduğunu ve bu yetersiz yeteneğin öğrencilerin bir vaka temelli akıl yürütme yaklaşımı gösterdiğini ortaya koymaktadır. Bu kusurlu akıl yürütme öğrencilerin temel adımları anlamadan mekanizmaları yeniden üretmelerine izin vermiştir. Dahası, katılımcıların, akıl yürütme süreçlerini göreve adapte etmek yerine görevi yerine getirme eğiliminde oldukları gözlenmiştir. Literatürde yapılan çalışmalar dikkate alındığında akıl yürütme kavramının öneminin arttığı, kimya konusunda akıl yürütme kavramının araştırmalarla desteklendiği ve yurt içinde yeni bir akıl yürütme alanı olarak alan yazına girdiği görülmektedir. Ayrıca yurt içinde yapılan çalışmalar incelendiğinde fen bilgisi öğretmeni adayları üzerinde faz dengeleri, termokimya ve termodinamik konularında öğretmen adaylarının akıl yürütme becerilerinin ve düşmüş olduğu hataların detaylı bir şekilde incelenmemiş olması araştırmanın özgün yönünü güçlendirmektedir.

\section{Çalışmanın Amacı}

$\mathrm{Bu}$ çalışmanın amacı fen bilgisi öğretmen adaylarının kimyasal reaksiyonlar, kinetik molekül teorisi, faz dengeleri, termokimya ve termodinamik konularındaki akıl yürütmelerini incelemektir. $\mathrm{Bu}$ genel amaç doğrultusunda aşağıda verilen problem cümlelerine cevap aranmıştır:

1. Fen bilgisi öğretmen adaylarının araştırma kapsamına alınan kimya konularında doğru akıl yürütmeleri nelerdir?

2. Fen bilgisi öğretmen adaylarının araştırma kapsamına alınan kimya konularında doğru olmayan akıl yürütmeleri nelerdir?

\section{Yöntem}

Çalışma sayısal veriler içermesi nedeniyle nicel araştırma yöntemlerinden tarama modeline göre yürütülmüştür. Tarama modelleri, çok sayıda katılımcıdan oluşan bir evrende, evrenin bütünü hakkında genel bir yargıya varmak amaciyla, evrenin tümünün ya da ondan alınacak bir bölümün (örneklemin) üzerinde yapilan düzenlemelerdir (Karasar, 1995). Tarama modelinde olayları olduğu gibi kaydetme ve sınıflama bilinen ilk özelliktir. Ancak tarama modelinde yorum ve değerlendirme yapmak zorunludur. Bu modelde belli bir zamanda çok geniş bir sahada bilgi toplamak hedeflenir. Toplanan veriler istatistiksel işlemlere elverişli olacak şekilde pek çok sayıda durum veya olaylara ait olmalıdır (Yıldırım, 1966,67-68). Tarama desenindeki çalışmalardaki asıl amaç; çalışılan örneklem grubunun, değişkenle ilgili görüntüsünü ortaya koymaktır (Gravetter ve Forzano, 2006; Leedy ve Ormrod, 2001). Araştırma, tarama modellerinden kesitsel tarama modeline uygun olacak şekilde yürütülmüştür. Fraenkel ve Wallen (2006) kesitsel tarama modelini değişkenlerin bir kere ölçüldüğü, diğer değişkenlere göre herhangi bir farklılık gösterip göstermediğinin belirlenmeye çalışıldığı araştırma modeli olarak tanımlamışlardır. Benzer şekilde Ayas ve Horzum (2012) kesitsel tarama modelini 
değişkenlerin anlık olacak şekilde bir kez ölçüldüğü bir model olarak ifade etmişlerdir. Yine Metin (2012) kesitsel taramada veri toplama sürecinin bir seferde gerçekleştirildiğini, veri toplamanın evrenin her hangi bir andaki fotoğrafını çekmeye benzediğini ifade etmiştir. Bu doğrultuda çalışmada fen bilgisi öğretmeni adaylarının bazı kimya konularında akıl yürütmelerini tek seferde tespit etmek amaciyla kesitsel tarama yöntemi tercih edilmiştir.

\section{Araştırmanın Katılımcıları}

$\mathrm{Bu}$ çalışmanın evrenini 2016-2017 bahar döneminde Fırat Üniversitesi Eğitim Fakültesi Fen Bilgisi eğitimi bölümünde öğrenim görmekte olan öğrenciler oluşturmaktadır. Araştırmanın örneklemini ise ilgili bölümden seçilen 210 (180 Kadın, 30 Erkek) fen bilgisi öğretmeni adayı oluşturmaktadır. İlgili bölüme bu öğretmen adayları yerleştirilirken ÖSYM (Öğrenci Seçme ve Yerleştirme Merkezi) tarafından yapılan merkezi sınava ait sayısal puanları dikkate alınmıştır. Dolayısıyla bu bölümü tercih eden fen bilgisi öğretmeni adayları ilgili oldukları liselerin sayısal (Matematik-Fizik-Kimya-Biyoloji) bölümlerinden gelmektedirler. Ayrıca almış oldukları lisans eğitim müfredatı incelendiğinde de birinci sınıfın ilk döneminde Genel Kimyave Genel Kimya Laboratuvarı derslerini aldıkları görülmektedir. Bu derslerin müfredatları incelendiğinde; kimyanın tanımı, alanları, önemi, yaşantımıza etkisi ve kimyanın tarihsel gelişimine kısa bir bakış, madde ve maddenin özellikleri, bilimsel yöntem, anlamlı sayılar, maddenin özellikleri, sınıflandırılması, atom ve atomun elektron yapısı, atom çekirdeği, atom kuramları, elektron yapısı, kimyasal bileşikler, periyodik çizelgeye giriş, bileşik çeşitleri ve formülleri, kimyasal reaksiyonlar, kimyasal eşitlikler, asit-baz reaksiyonları, yükseltgenme-indirgenme reaksiyonları, gazlar, ideal gazlar, ideal olmayan gazlar, termokimya, entalpi, iç enerji, entropi, periyodik çizelge, elementlerin sınıflandırılması, periyodik özellikleri, kimyasal bileşikler, bileşiklerin oluşumu, hibritleşme, hibritorbitalleri oluşumu ve molekül geometrisi, formülleri, çeşitleri ve özellikleri, kimyasal bağlar, temel kavramlar, bağ kuramları ve bağ çeşitleri, asit-baz titrasyonu, kütlenin korunumu, gazların difüzyonu, bir metalin $\mathrm{HCl}$ asit ile reaksiyonu, tersinir reaksiyonlar, temas yüzeyinin reaksiyon hızına etkisi, destilasyon deneyi, 1 . ve 5 . grup katyonların sistematik analizi ve sabun sentezi konu başlıklarının bulunduğu görülmektedir. Fen bilgisi öğretmeni adaylarının 1. Sınıfın güz döneminde ilgili dersleri almış olması sebebiyle hazırbulunuşluk düzeylerinin benzer olduğu varsayılmıştır. Bu çalışmada fen bilgisi öğretmeni adaylarından kullanılan testin yeterliğine ilişkin ayrıntılı bilgi alınması ve öğrencilerin kimya konuları ile ilgili akıl yürütmelerinin incelenmesi öngörüldüğünden amaçlı örnekleme yöntemi kullanılmıştır. Amaçlı örnekleme çalışmanın amacına bağlı olarak bilgi açısından zengin olayların/durumların seçilerek derinlemesine araştırmasına olanak sağlar (Büyüköztürk, Çakmak, Akgün, Karadeniz, ve Demirel, 2016: 90). Çalışmaya katılımda gönüllülük esas alınmıştır. Çalışmaya katılanlar gönüllü olduklarına dair bir formu doldurup imzalamışlardır. Formda testin amacı ve uygulanması ile ilgili ayrıntılı bilgiler yer almaktadır. Ayrıca, katılımcılara bu testin sadece bilimsel bir çalışma için uygulandığı, testten aldıkları puanların onların ders notlarına yansıtılmayacağı özellikle bildirilmiştir. Son olarak katılımcılardan test üzerine isim 
yazmamaları da istenmiştir. Seçilen katılımcıların sınıf ve cinsiyetlerine göre dağılımları aşağıdaki tabloda verilmiştir.

Tablo 1.

Katılımcıların Sinıf ve Cinsiyetlerine Göre Dă̆llımları

\begin{tabular}{cccc}
\hline Katılimcilar & Kiz & Erkek & Toplam \\
\hline 1. Sinif & 38 & 14 & 52 \\
\hline 2. Sinif & 46 & 6 & 52 \\
\hline 3. Sinif & 42 & 6 & 48 \\
\hline 4. Sinif & 54 & 4 & 58 \\
\hline Genel Toplam & 180 & 30 & 210 \\
\hline
\end{tabular}

\section{Veri Toplama Araçları}

Çalışmada Cloonan ve Hutchinson (2011) tarafindan geliştirilmiş olan "Kimya Konuları Akıl Yürütme Testinin kimyasal reaksiyonlar, kinetik molekül teorisi, faz dengeleri, termokimya ve termodinamik bölümleri veri toplama aracı olarak kullanılmıştır. Fen bilgisi öğretmeni adaylarının birtakım demografik bilgilerini toplamak amacıyla ayrıca bir demografik bilgi formu da kullanılmıştır.

Kimya Konuları Akıl Yürütme Testi Cloonan ve Hutchinson (2011) tarafından geliştirilmiştir. Testin A ve B şeklinde kodlanmış iki versiyonu mevcuttur. Soruların benzer becerileri ölçmesi sebebiyle bu çalışmada kullanılmak üzere A versiyonu seçilmiştir. Araştırma kapsamına alınan konulara ilişkin testin konu ve soru dağılımı Tablo 2'de verilmiştir.

Tablo 2.

Kimya Konuları Akıl Yürütme Testinde Yer Alan Konular

\begin{tabular}{lll}
\hline & Konu (İçerik) & Konuyla ilgili maddeler \\
\hline 1. & Kimyasal reaksiyonlar & $1,2,3,4$ \\
\hline 2. & Kinetik molekül teorisi & $5,24,25$ \\
\hline 3. & Faz dengeleri & $26,27,28,29$ \\
\hline 4. & Termokimya & $11,12,19,20$ \\
\hline 5. & Termodinamik & $21,22,23,34$ \\
\hline
\end{tabular}

Tablo 2'de yer alan konuların tamamı ülkemizde yer alan eğitim fakültelerinin fen bilgisi öğretmenliği programında okumakta olan öğretmen adaylarına genel kimya dersleri kapsamında öğretilmektedir. Test, içerdiği çoktan seçmeli maddelerin özellikleri bakımından hem kimyayı anlamayı hem de kimya konularında akıl yürütmeyi ölçecek düzeydedir. Testte yer alan maddeler, görselleştirme, mantıksal akıl yürütme ve özel açıklamalar gerektiren sorulardan oluşmaktadır. Böylelikle katılımcıların kimyayı anlamaları araştırılabilmektedir. Öğrenciden olası cevabın doğruluğunu değerlendirmesi istenir (Cloonan ve Hutchinson, 2011).

\section{Testin Türkçeye Uyarlanması}


Kimya Kavramları Akıl Yürütme Testi (KKAYT)'nin Türk dili ve kültürüne uyarlanması sürecinde test iki ayrı İngiliz Dili uzmanı tarafından incelenmiştir. Dil uzmanlarından biri testi önce Türkçe'ye çevirmiş, ardından diğer dil uzmanı Türkçe'ye çevrilen bu testi tekrar İngilizce'ye çevirmiştir. İngilizce metin tekrar Türkçe'ye çevrilerek çeviriler karşılaştırılmıştır. Daha sonra her bir madde için öğretmen adaylarında görmek istenilen özellikleri karşılayıp karşılamadığına ilişkin alan uzmanı görüşü alınmıştır. Test maddelerine ilişkin görüş ve öneriler değerlendirilerek ve gerekli düzeltmeler yapıldıktan sonra teste son şekli verilmiştir. Böylece çevirilerin dil geçerliği sağlanmaya çalışılmıştır.

\section{Testin Güvenirliği}

Bilimsel araştırmalarda geçerlilik son derece önemlidir. Geçerlilik bir ölçme aracının ölçülmek istenen bir özelliği doğru olarak ölçebilme derecesi olarak tanımlanabilir. Geçerlilik, bilimsel çalışmalarda kullanılan ölçme aracının kalitesini ortaya koyar (Büyüköztürk, Kılıç Çakmak, Akgün, Karadeniz ve Demirel, 2015). Bu çalışmada kullanılan KKAYT Cloonan ve Hutchinson (2011) tarafindan geliştirilmiştir. $\mathrm{Bu}$ araştırmacılar geliştirdikleri ölçme aracının geçerli olduğunu rapor etmişler ve testin kapsam geçerliliğinin uzmanlardan görüş alınarak belirlendiğini belirtmişlerdir. Testin kimyayı anlama ve kimya konularında akıl yürütme seviyeleri düşük ve yüksek olan bireyleri birbirinden ayırt edip etmediğini belirlemek amacıyla alanı kimya olmayan bilim insanlarından da görüş alındığı testi geliştiren bilim adamları tarafından ifade edilmektedir. Cloonan ve Hutchinson (2011) testin kriter geçerliliğinin de sağlandığını bildirmişlerdir. Bunun için ise bu testi bir grup öğrenciye uyguladıklarını, elde etikleri sonuçları ise aynı öğrencilerin kimya ile ilgili olarak daha önceden yapılmış başka testlerin sonuçları ile mukayese ettiklerini bildirmişlerdir. Ölçme aracı 2 program geliştirme alan uzmanına, 3 ölçme değerlendirme alan uzmanına ve 3 fen bilgisi öğretmenine gösterilerek, ölçme aracının görünüş geçerliliği ile ilgili görüş alınmıştır. Görünüş geçerliliği, bir ölçme aracının ismi, açıklamaları ve sorularıyla ölçmeyi amaçladığı özelliği ölçüyor görünmesidir (Büyüköztürk, Kılıç Çakmak, Akgün, Karadeniz ve Demirel, 2015). Testin kapsam geçerliliğini sağlamak amacıyla kimya alanında uzman 2, fen bilgisi alanında uzman 1 öğretim üyesinin görüşü alınmıştır.

\section{Veri Toplama Süreci}

Testler 2016-2017 bahar dönemi sonunda Fırat Üniversitesi Eğitim Fakültesi Fen Bilgisi Öğretmenliği programı 1., 2., 3. ve 4. sınıflarında okuyan öğretmen adaylarına uygulanmıştır. Araştırmada toplam 219 katılımcıya ulaşılmış, bu katılımcıların 9' unun test uygulamalarında yanlış veya eksik işaretlemeler yapmış olmaları sebebiyle araştırmaya dâhil edilmemiş, geriye kalan 210 katılımcının teste vermiş oldukları cevaplar değerlendirmeye alınmıştır. Öğretmen adaylarına testte yer alan soruları cevaplamaları için 1 saat süre verilmiştir. Öğretmen adaylarından ek süre talebi gelmemesi nedeniyle bu sürenin yeterli olduğu kanaatine ulaşılmıştır. Testin uygulanması esnasında araştırmacılar katılımcıların anlamadığı veya açıklanmasını istediği hususlarda gerekli açıklamayı yapmışlardır. Ayrıca katılımcılara testte bulunan elementlerin atom numaralarına bakmaları amacıyla peryodik cetvel dağıtılmıştır. 


\section{Verilerin analizi}

Çalışma uygulamaları sonucunda elde edilen veriler bilgisayar ortamına girilerek, SPSS 23.00 paket programı ile analiz edilmiştir. Araştırmada öncelikle öğretmen adaylarının her bir konu boyutunda kimya konuları ile ilgili akıl yürütmelerine ilişkin betimsel istatistikler, yapmış oldukları doğru-yanlış oranları araştııılmıştır. $\mathrm{Bu}$ doğrultuda fen bilgisi öğretmeni adaylarının kimyasal reaksiyonlar, kinetik moleküler teorisi,faz dengeleri, termokimya ve termodinamik kavramlarına ilişkin doğru ve yanlış akıl yürütmeleri incelenmiştir.

\section{Bulgular ve Yorum}

\section{Kimyasal Reaksiyonlar}

Kimya Konuları Akıl Yürütme Testinde kimyasal reaksiyonlar konusuyla alakalı olarak dört soru vardır . Bu sorularda fen bilgisi öğretmeni adaylarından bir kimyasal reaksiyonun denkleştirilmesi, sınırlayıcı bileşen ve farklı kütlelerde ürün ve girenlerin olduğu reaksiyon gibi konularda akıl yürütmeleri istenmiştir.

Tablo 3.

Kimyasal Reaksiyonlar Konusundaki Sorulara Verilen Cevapların Saylsı ve Yüzdesi

\begin{tabular}{ccccccc}
\hline Soru & \multicolumn{7}{c}{ Çeldiriciler-Frekans(Yüzde) } \\
\cline { 2 - 7 } & $\mathrm{A}$ & $\mathrm{B}$ & $\mathrm{C}$ & $\mathrm{D}$ & $\mathrm{E}$ & $\mathrm{F}$ \\
\hline 1 & $12(5.7)$ & $\mathbf{1 4 4 ( 6 8 . 6})^{*}$ & $4(1.9)$ & $48(22.9)$ & $2(1.0)$ & - \\
\hline 2 & $9(4.3)$ & $49(23.3)$ & $\mathbf{1 3 5 ( 6 4 . 3})^{*}$ & $11(5.2)$ & $6(2.9)$ & - \\
\hline 3 & $40(19.0)$ & $11(5.2)$ & $\mathbf{7 1 ( 3 3 . 8})^{*}$ & $4(1.9)$ & $59(28.1)$ & $25(11.9)$ \\
\hline 4 & $\mathbf{7 6 ( 3 6 . 2})^{*}$ & $16(7.6)$ & $76(36.1)$ & $34(16.2)$ & $8(3.8)$ & - \\
\hline
\end{tabular}

*: Doğru cevapların ortalama yüzdesi \% 50.7 'dir.

Soru 1: Bu soruda bir kimyasal reaksiyonun denkleştirilmesi istenmiştir. Soruda iki diatomik molekülden bir tane triatomik molekül oluşması reaksiyonu verilmiş ve reaksiyonun denkleştirilmiş hali sorulmuştur. Sorudaki resimde, siyah daireler “ $\bullet$ ” $\mathrm{X}$ elementinin atomlarını, beyaz dairelerin "O" ise Y elementinin atomların temsil etmektedir. Moleküller ise bitişik dairelerle temsil edilmiştir. Örneğin, $X_{2}={ }^{\prime \prime} \bullet$ şeklindedir. Verilen reaksiyon eşitliklerinden hangisinin resmedilen reaksiyonu temsil ettiği sorulmuştur. Moleküllerin ve reaksiyonun resimsel gösterimi şu şekildedir.

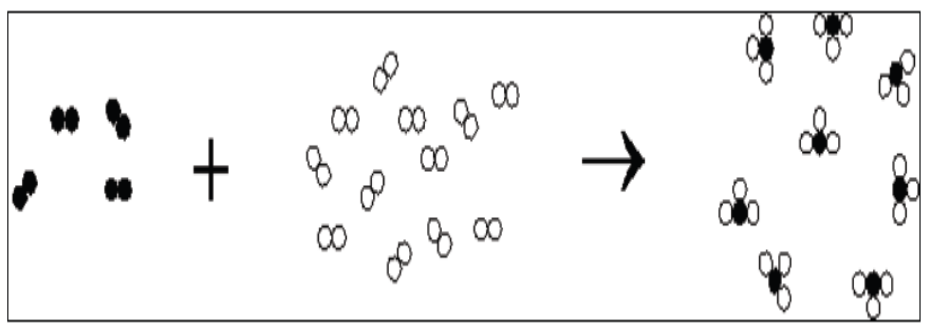


Bir kimyasal reaksiyonun denkleştirilmesi, reaksiyon denkleminin her iki yanında aynı sayıda atomun varlığının sağlanması ile olur (Petrucci ve diğerleri, 2002). Kimyasal reaksiyonlar denkleştirilirken en küçük tam katsayılar kullanılır. Bu açıklamalardan da anlaşılacağı üzere bu soruya doğru cevap $\mathrm{B}$ seçeneğidir $\left(\mathrm{X}_{2}+3 \mathrm{Y}_{2}\right.$ $\left.\rightarrow 2 \mathrm{XY}_{3}\right)$.

Tablo 3 verileri incelendiğinde, fen bilgisi öğretmeni adaylarının \% 68.6'sının (B Şıkkı) bu soruyu doğru bir şekilde yanıtladığı görülmektedir. Bununla birlikte \% 22.9 'u, katsayıları en küçük tam sayılara indirmeden D'yi seçmiştir $\left(4 \mathrm{X}_{2}+12 \mathrm{Y}_{2} \rightarrow\right.$ $8 \mathrm{XY}_{3}$ ). $\mathrm{Bu}$ sebeple, bu şıkkı işaretleyen fen bilgisi öğretmeni adaylarının, denkleştirilmiş bir kimyasal denklemdeki katsayıların en küçük tam sayı oranlarında olması gerektiği bilgisinden yoksun olduğunu söylemek mümkündür. Fen bilgisi öğretmeni adaylarının \% 5.7'si A şıkkını seçmiştir. Bu durum bu şıkkı işaretleyen fen bilgisi öğretmeni adaylarının, reaksiyona girenlerin moleküller olduğunun gösterimle belirtilmiş olmasına rağmen reaktifleri atom olarak düşündükleri anlaşılmaktadır. $\left(\mathrm{X}+3 \mathrm{Y} \rightarrow \mathrm{XY}_{3}\right)$.

Soru 2: Bu soru, soru 1 de verilen reaksiyon gösterimi ile alakalıdır. Tek farklı olan kısmı reaksiyona girenlerden birinin fazla olmasıdır. Bu soru ile fen bilgisi öğretmeni adaylarının sınırlayıcı bileşen hakkındaki akıl yürütmeleri irdelenmiştir. Soruda denkleme daha fazla $\mathrm{X}$ eklendiğinde, reaksiyon yeniden aşağıdaki resimde olduğu gibi düzenlendiğinde, reaksiyonu en iyi şekilde tamamlayacak resmin nasıl olduğu sorulmuştur.

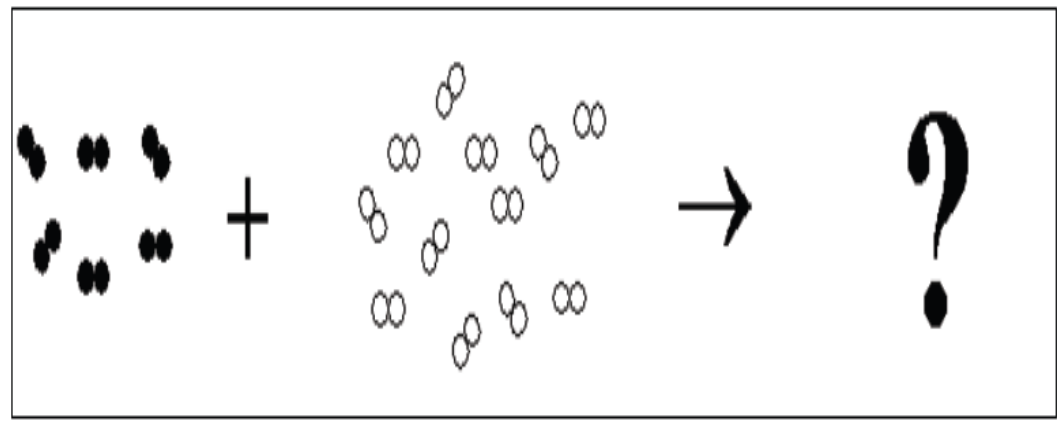

Stokiyometrik olmayan oranlarda iki veya daha fazla tür kimyasal bir reaksiyona girdiğinde, reaksiyonun son hali reaksiyonda tamamen tükenen reaktif tarafından belirlenir. $\mathrm{Bu}$ reaktif sınırlayıcı bileşendir ve ürünlerin miktarını da bu sınırlayıcı bileşen belirler (Silberberg, 2013). Tüm reaktifler tükenmiş olmasına rağmen, fazla miktarda bulunan reaktif/reaktiflerin bir kısmı reaksiyona girmeden kalacaktır. Bu açıklamalardan da anlaşılacağı üzere bu sorunun cevabı $\mathrm{C}$ seçeneğidir. $\mathrm{Bu}$ seçenek $\mathrm{X}$ molekülünün bir atomunun $\mathrm{Y}$ molekülünün üç atomuyla birleşerek sekiz $\mathrm{XY}_{3}$ molekülü oluşturduğunu göstermektedir. Sınırlayıcı reaktif $\left(\mathrm{Y}_{2}\right)$ tükendikten sonra, $\mathrm{X}_{2}$ 'nin fazla iki molekülü kalmaya devam eder. 
Tablo 3 verileri incelendiğinde, fen bilgisi öğretmeni adaylarının \% 64.3'ünün (C Şıkkı) doğru cevabı seçtiği görülmektedir. Bununla birliktefen bilgisi öğretmeni adaylarının, \% 23.3 'si B'yi seçmiştir; bu seçenek, tepkime sona erdiğinde fazla reaktif moleküllerin hâlâ mevcut olduğunu göstermemektedir. Ayrıca, bu yanıt, fen bilgisi öğretmeni adaylarının soru 2'yi soru 1 ile ilişkilendiremediğini göstermektedir. Her iki sorudaki tepkime maddeleri ve reaksiyonların ürünleri aynıdır. B seçeneği, X atomlarının ve Y atomlarının farklı kombinasyon oranlarını göstermektedir. $\mathrm{Bu}$ şıkk1 işaretleyen fen bilgisi öğretmeni adayları artan madde olmasına rağmen reaksiyondaki tüm reaktiflerin tükendiğini düşünmektedirler. $\mathrm{Bu}$ fen bilgisi öğretmeni adayları sınırlayıcı reaktifin reaksiyonun sonucunu belirleyeceği düşüncesinden yoksundur. Fen bilgisi öğretmeni adaylarının \% 5.2'lik (D Şıkkı) kısmı ise, sınırlayıcı reaktif ve birleşme oranları kavramlarından yoksul bir şekilde akıl yürütmüşlerdir.

Soru 3:Bu soruda su ve oksijenin kütlelerindeki farklılık esas alınmıştır. Soruda aynı sıcaklık ve basınçta aynı hacimdeki su ve oksijenden suyun ağırlığının neden oksijenin ağırlığından az olduğu sorulmuştur.

Bir su molekülü $\left(\mathrm{H}_{2} \mathrm{O}\right)$ iki hidrojen atomu ve bir oksijen atomu içerirken bir oksijen molekülü iki oksijen atomuna $\left(\mathrm{O}_{2}\right)$ sahiptir. Böylece su molekülünün $\left(\mathrm{H}_{2} \mathrm{O}\right)$ molekül ağırlığı 18 gram iken, oksijen molekülünün $\left(\mathrm{O}_{2}\right)$ ise 32 gramdır. $\mathrm{Bu}$ nedenle, bir su molekülü, bir oksijen molekülünden daha düşük ağırlığa sahiptir.

Tablo 3 verileri incelendiğinde, fen bilgisi öğretmeni adaylarının \% 33,8'inin (C Şıkkı) bu soru için doğru yanıt verdiği görülmektedir. C seçeneği şöyledir: Bir su molekülü sadece bir oksijen atomu içerir ve bu nedenle bir oksijen molekülünden daha az ağırlığa sahiptir. Fen bilgisi öğretmeni adaylarının, \%28.1'i (E Şıkkı) hidrojenin oksijenden daha hafif olmasının böyle bir sonuç doğurduğunu düşünmektedirler. $\mathrm{Bu}$ öğretmen grubu, mantıklarını oksijen ve hidrojenin yoğunluklarına dayandırmıştır. Fen bilgisi öğretmeni adaylarının \% 19'luk (A Şıkkı) bir kısmı hidrojenin sınırlayıcı bileşen olduğu için oksijeninin tamamı reaksiyona girmediğine ve böylelikle de ürünün tartıldığına fakat reaksiyona girmeyen oksijenin tartılmadığını düşünmektedir. $\mathrm{Bu}$ seçeneği seçen öğretmen adayları, sınırlayıcı reaktif hakkında yeterli bilgiye sahip değildirler. Hidrojen fazladır, bu yüzden sınırlayıcı reaktif değildir. Bu nedenle oksijenin reaksiyona girmemiş bir kısmı yoktur.

Soru 4: Bu soruda bir kimyasal maddenin mol sayısının bilinmesinin önemi sorulmuştur. Diğer bir deyişle, neden mol sayısının belirlenmeye çalışıldığı sorulmuştur.

Mol, madde miktarını ifade etmede kullanılan ve SI birimleri içerisinde yer alan bir ölçü birimi olup avagadro sayısı kadar $\left(6.022 \times 10^{23}\right)$ atom, molekül veya iyonu ifade eder. Mol sayısı örnek olarak verilen bir kimyasal maddede ne kadar atom, molekül veya iyon olduğunu ve böylelikle de bir kimyasal reaksiyon için ne kadar maddeye ihtiyacımız olduğunu bilmemizi sağlar. Yapılan açıklamalardan da anlaşılacağı üzere biz mol sayısını biliyorsak parçacık (atom, iyon veya molekül) 
sayısı hakkında bilgi sahibi oluyoruz demektir. $\mathrm{Bu}$ durumda, doğru yanıt $\mathrm{A}$ seçeneğidir.

Fen bilgisi öğretmeni adaylarının \% 36,2'si (A Şıkkı) bu soru için doğru mantığ sağlamıştır. Bununla birlikte, \%36.1'lik (C Şıkkı) bir kısım "mol sayısını biliyorsak, ne kadar kütlenin bulunduğunu belirleyebiliriz" düşüncesine sahiptir. $\mathrm{Bu}$ mantık, öğretmen adaylarının mol kavramının madde miktarını ifade etmede kullanılan bir kavram olduğunu anlamadıklarını göstermektedir. Bu öğretmen adayları molü kütle gibi diğer nicelik birimlerine benzetmişlerdir. Fen bilgisi öğretmeni adaylarının \% 16.2'si (D Şıkkı), mol sayısını bilmenin kimyasal hesaplamalar için, kütlesel anlamda uygun bir dönüşüm faktörü sağlayacağını ve bu nedenle de mol sayısının önemli olduğunu ifade etmektedirler. Fen bilgisi öğretmeni adaylarının \% 7.6's1 (B Şıkkı), mol sayısının bilinmesi ile bir reaksiyon sonrasında ne kadar maddenin artacağını belirleyebileceğimizi düşünmektedir. $\mathrm{Bu}$ öğretmen adayları, "mol" kelimesinin bir maddenin miktarını ifade ettiğini bilmemektedirler. Bu nedenle mol sayısını bilmek, parçacıkları (molekülleri, iyonları veya atomları) esasen saydığımızı gösterir.

\section{Kinetik Molekül Teorisi}

Kimya Konuları Akıl Yürütme Testinde kinetik molekül teorisi konusuyla alakalı olarak üç soru vardır (5., 24. ve 25. sorular). Bu sorularda sabit basınç ve sıcaklıkta hacimleri eşit olan iki ayrı gazın mol sayıları ile ideal gazlarda hacim ve basınç arasındaki ilişki esas alınmıştır.

Tablo 4.

Moleküler Enerji Teorisi Konusundaki Sorulara Verilen Cevapların Sayıs ve Yüzdesi

\begin{tabular}{ccccccc}
\hline \multirow{2}{*}{ Soru } & \multicolumn{6}{c}{ Çeldiriciler-Frekans(Yüzde) } \\
\cline { 2 - 7 } & A & B & C & D & E & F \\
\hline 5 & $29(13.8)$ & $\mathbf{5 2 ( 2 4 . 8})^{*}$ & $99(47.1)$ & $28(13.3)$ & $2(1.0)$ & - \\
\hline 24 & $21(10.0)$ & $\mathbf{1 4 5 ( 6 9 . 0} *$ & $20(9.5)$ & $14(6.7)$ & $10(4.8)$ & - \\
\hline 25 & $30(14.3)$ & $\mathbf{1 0 9}(\mathbf{5 1 . 9}) *$ & $39(18.6)$ & $23(11.0)$ & $4(1.9)$ & $5(2.4)$ \\
\hline *: Doğru cevapların ortalama yüzdesi \% & 48.5 'dir. & & &
\end{tabular}

Soru 5:Bu soruda sabit basınç ve sıcaklıkta hacimleri eşit olan iki ayrı gazın mol sayılarının aynı olduğu belirtilmiş ve bu ifadenin doğru olduğunu gösteren en iyi verinin şıklarda verilenlerden hangisi olduğu sorulmuştur. Soru avagadro kurallarını esas almaktadır. Avagadro kuralına göre sabit basınç ve sıcaklıkta hacimleri eşit olan iki ayrı gazın tanecik veya mol sayıları eşittir. (Petrucci, Harwood, ve Herring, 2002). Böylece, sabit basınç ve sıcaklıkta bir gaz tarafından işgal edilen hacim, doğrudan gazın miktarı ile orantılıdır. Buradan, sabit basınç ve sıcaklıkta gazların reaksiyonlarının hacimlerin basit tamsayı oranlarını esas alacak şekilde gerçekleşeceği sonucuna ulaşılır. Dolayısıyla bu soru için doğru cevap B şıkkıdır (Sabit sıcaklık ve basınçta, gazlar hacimsel olarak basit tamsayı oranlarında tepkime verirler). 
Tablo 4 verileri incelendiğinde, fen bilgisi öğretmeni adaylarının \% 24.8'inin (B Şıkkı) bu soruyu doğru cevapladığı görülmektedir. Fen bilgisi öğretmeni adaylarının çoğu (\% 47.1) C'yi seçmiştir. Bu yanıt seçeneği, gazların sadece sabit basınç ve sıcaklıkta ideal gaz kanununa uyduğunu önermektedir. Buna ek olarak,\% 13.8'lik (A Şıkkı) bir kısım sabit basınç ve sıcaklıkta gaz moleküllerinin aynı hacimde olduğunu belirten seçeneği seçmişlerdir. Bu öğretmen adayları Avogadro yasasını anlamamıştır.

Soru 24: Bu soru ideal gaz yası ile ilgilidir. Soruda bir ideal gaz için hacim ve basınç arasındaki ilişkinin en iyi şekilde nasıl ifade edildiği sorulmuştur (sıcaklık ve madde miktarı sabit ).

$\mathrm{Bu}$ soru Boyle yasası ile ilgilidir. Boyle yasasına göre, bir kabın hacmi azaltılırsa birim hacme düşen çarpma sayısı artar. $\mathrm{Bu}$ da gazın kaba uyguladığı basıncının artmasına neden olur. Şayet kabın hacmi artırılırsa içinde bulunan gazın birim hacme düşen çarpma sayısı azalacağından gazın kaba uyguladığı basınçta azalır. Bu açıklamadan da anlaşılacağı üzere bu soru için doğru yanıt B şıkkıdır.

Tablo 4 verileri incelendiğinde, fen bilgisi öğretmeni adaylarının \% 69'unun (B Şıkk1) Boyle yasası üzerinde doğru akıl yürüttüğü görülmektedir. Bununla birlikte, sabit sıcaklıkta sabit bir gaz miktarının basıncının hacmiyle doğrudan orantılı olduğunu düşünenlerin oranı\% 10'dur (A Şıkk1). Bu yanıtı işaretleyenfen bilgisi öğretmeni adaylarının Boyle yasasını anlamadığı aşikârdır.

Soru 25: Bu sorudaSoru 24'te ifade edilen hacim ve basınç arasındaki ilişkiyi teorik olarak en iyi şekilde açıklayan ifadenin hangi şıkta verildiği sorulmuştur.

Soru 24 te verilen ilişkinin açıklaması şu şekildedir; kabın hacmi artırılırsa içinde bulunan gazın birim hacme düşen çarpma sayısı azalacağından gazın kaba uyguladığı basınçta azalır. Çünkü basınç, birim yüzey alanı için uygulanan kuvvet olarak tanımlanmaktadır (Zumdahl ve Zumdahl, 2010). Dolayısıyla bu soru için doğru cevap B şıkkıdır.

Tablo 4 verileri incelendiğinde, fen bilgisi öğretmeni adaylarının \% 51.9'unun (B Şıkkı) 25. soruya doğru yanıt verdikleri görülmektedir. Bazı fen bilgisi öğretmeni adayları (\% 18.6) artan basınç kabın hacmini artırdığını düşünmektedir (C şıkkı). Bu öğretmen adayları, hacim ve basınç arasında doğrudan bir ilişki olduğunu düşünmektedirler. Öğretmen adaylarının yaklaşık yarısının hacim ve basınç arasındaki ilişki üzerine akıl yürütmelerinin yanlış olduğu sonucuna ulaşılmıştır.

\section{Faz Dengeleri}

Kimya Konuları Akıl Yürütme Testinde faz dengeleri konusuyla alakalı olarak dört soru vardır (26., 27., 28. ve 29. sorular). Bu sorularda fen bilgisi öğretmeni adaylarının faz dengeleri ile ilgili akıl yürütmeleri incelenmiştir.

Tablo 5 .

Faz Dengeleri Konusundaki Sorulara Verilen Cevapların Sayısı ve Yüzdesi Çeldiriciler-Frekans(Yüzde) 


\begin{tabular}{ccccccccc}
\hline & $\mathrm{A}$ & $\mathrm{B}$ & $\mathrm{C}$ & $\mathrm{D}$ & $\mathrm{E}$ & $\mathrm{F}$ & $\mathrm{G}$ & $\mathrm{H}$ \\
\hline 26 & $24(11.4)$ & $\mathbf{7 6 ( 3 6 . 2})^{*}$ & $20(9.5)$ & $12(5.7)$ & $31(14.8)$ & $25(11.9)$ & $16(7.6)$ & $6(2.9)$ \\
\hline 27 & $\mathbf{4 1 ( 1 9 . 5 ) *}$ & $100(47.6)$ & $36(17.1)$ & $13(6.2)$ & $20(9.5)$ & - & - & - \\
\hline 28 & $\mathbf{5 5 ( 2 6 . 2} *$ & $59(28.1)$ & $46(21.9)$ & $28(13.3)$ & $22(10.5)$ & - & - & - \\
\hline 29 & $18(8.6)$ & $30(14.3)$ & $18(8.6)$ & $35(16.7)$ & $\mathbf{1 0 9}(\mathbf{5 1 . 9})^{*}$ & - & - & - \\
\hline
\end{tabular}

*: Doğru cevapların ortalama yüzdesi \% 33.4'dür.

Soru 26: Bu soruda bir maddenin moleküllerinin farklı sıcaklıklardaki halini gösteren bir dizi resim verilmiştir. Bu resimlerin artan sıcaklığı ifade edecek bir şekilde sıralanması istenmiştir. Verilen şekiller aşağıdaki gibidir.
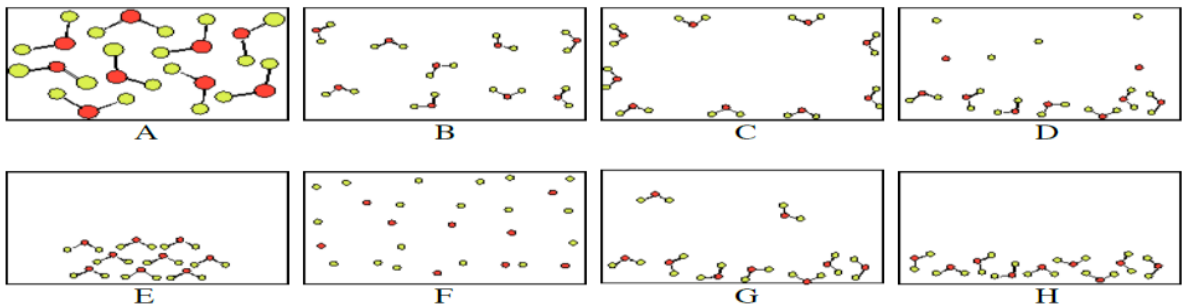

Maddeler doğada katı sıvı veya gaz halinde bulunur. Maddenin hangi halde olduğu ortamın sıcaklığına bağlıdır. Sıcaklık arttıkça parçacıkların ortalama kinetik enerjisi de artar, bu nedenle daha hızlı hareket eden parçacıklar tanecikler arası çekim kuvvetlerinin etkisinden daha kolay kurtulurlar. (Silberberg, 2013). Bu nedenle sıcaklık arttıkça parçacıklar birbirlerinden uzaklaşırlar. Yapılan bu açıklamadan da anlaşılacağı üzere bu soru için doğru cevap B şıkkıdır (EHGB şeklinde sıralama). Verilen resimlerden en iyi cevap EHGB (B Şıkkı) 'dir. D ve F ile belirtilen şekillerde ise moleküllerin atomlarına ayrılmış halleri vardır.

Fen bilgisi öğretmeni adaylarının \% 36.2'sinin (B Şıkkı) bu soru için doğru cevabı seçtiği görülmektedir. Öğretmen adaylarının üçte ikisine yakın bir kısmı bu soruyu doğru cevaplayamamıştır. Yanlış cevaplayanların bir kısmının (örneğin E şıkkını işaretleyenler) akıl yürütmeleri sıcaklık arttığında moleküllerin birbirlerine daha da yakınlaşacağı şeklindedir. Yanlış işaretleyen diğer öğretmen adaylarının akıl yürütmesi de sıcaklık arttıkça moleküllerin atomlara ayrıldığı yönündedir. $\mathrm{Bu}$ düşünceye sahip öğretmen adayları F şıkkını işaretlemiştir.

Soru 27: Bu soru buhar basıncı kavramıyla ilgilidir. SorudaA ve B olarak gösterilen iki şekil verilmiş, Pistonun şekil A'daki pozisyonundan şekil B'de belirtilen yüksekliğe çekilmesiyle hacim arttırıldığından bahisle, Şekil B'de denge tekrar kurulduktan sonra hangi durumun gerçekleşeceği sorulmuştur. Bahsedilen şekil aşağıda verilmiştir. 


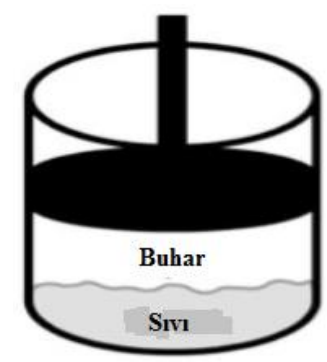

A

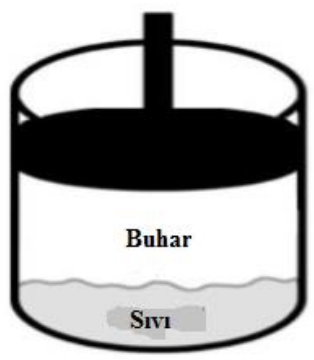

B

Dinamik denge durumundaki kapalı bir sistemde, buharın uyguladığı basınca buhar basincı denir (Petrucci, Harwood, ve Herring, 2002). Buhar basıncı yalnızca sıcaklık değişiminden etkilenir. Daha yüksek bir sıcaklıkta, daha fazla molekül sıvı fazından ayrılıp buhar fazına geçmek için yeterli enerjiye sahiptir. Daha düşük bir sıcaklıkta ise, daha az molekül, sıvı fazından ayrılıp buhar fazına geçmek için yeterli enerjiye sahiptir. Sadece sıcaklık buhar basıncını etkiler. Hacim değişikliğinin buhar basıncı üzerine hiçbir etkisi yoktur. Bu nedenle, buhar basıncı Şekildeki A ve B'de aynı kalacaktır ve doğru cevap A şıkkı olacaktır.

Tablo 5 verileri incelendiğinde, fen bilgisi öğretmeni adaylarının yalnızca \% 19,5'inin (A Şıkkı) bu soruyu doğru bir şekilde yanıtladığı görülmektedir. Bununla birlikte, basınç hacim ile ters orantılı olduğu için, öğretmen adaylarının \% 47.6'sı (B Şıkkı) buhar basıncının B'de A'dan daha düşük olacağını düşünmektedir. Bu şekilde bir düşünceye sahip olan öğretmen adayları buhar basıncı ve hacim arasındaki ilişkiyi basınç ve hacim arasındaki ilişkiden ayıramamışlardır. Öğretmen adaylarından \% 17.1'lik (C Şıkkı) bir kısım, artan hacmi doldurmak için B'deki buhar basıncının daha yüksek olacağını düşünmüştür. Bu şekilde bir düşünceye sahip olan öğretmen adayları, hacmin artırılmasıyla buhar basıncının arttığını düşünmektedir.

Soru 28:Bu soru ile öğretmen adaylarının 27. soruya vermiş oldukları cevabın nedeni araştırılmıştır. Denge yeniden kurulduğunda, yoğunlaşma oranı ve buharlaşma oranı değişmez dolayısıyla bu soru için doğru cevap A şıkkıdır.

Tablo 5 verileri incelendiğinde, fen bilgisi öğretmeni adaylarının \% 26.2'sinin (A Şıkkı) doğru cevap verdiği görülmektedir. Öğretmen adaylarının \% 28.1'i (B Şıkkı) hacmin artmasıyla daha az buhar molekülü sıvı yüzeyi ile temas edeceği için yoğunlaşma oranı daha azdır. Bazı fen bilgisi öğretmeni adayları (\% 21.9) sıvı ile temas eden daha fazla buhar molekülü olduğu için yoğuşma oranının daha büyük olduğunu (C Şıkkı) düşünmektedir. Öğretmen adaylarının \% 13.3’ü (D Şıkkı) buhar molekülleri için daha fazla alan bulunması sebebiyle buharlaşma oranının daha büyük olduğunu düşünmektedir. $\mathrm{Bu}$ tür akıl yürütme, bu şıkları işaretleyen fen bilgisi öğretmeni adaylarının dengenin yeniden kurulduğu söylenmesine rağmen sistemin artık dinamik dengede olmadığını düşündüklerini göstermektedir. 
Soru 29: $\mathrm{Bu}$ soruda aynı sıcaklık ve basınç altında su $\left(\mathrm{H}_{2} \mathrm{O}\right)$ ve metanın $\left(\mathrm{CH}_{4}\right)$ fiziksel hallerindeki farklılığın (su sıvı, metan gaz) nedeni sorulmuştur.

Moleküller arası kuvvetler her maddedeki moleküller arasında vardır. Moleküller arası kuvvetler bir maddenin fiziksel durumunu belirler. Soruda verilen bu durum aynı sıcaklık ve basınçta suyun metanla karşılaştırıldığında daha güçlü moleküller arası kuvvetlere sahip olduğunu gösterir. Dolayısıyla bu soru için doğru yanıt E seçeneğidir.

Tablo 5 verileri incelendiğinde, Fen bilgisi öğretmeni adaylarının \% 51.9 'unun (E Ş1kk1) bu konu ile ilgili doğru akıl yürütmeye sahip olduğu görülmektedir. \% 16.7 'lik (D Şıkkı) bir grup su moleküllerinin metan moleküllerinden daha ağır olması nedeniyle böyle bir durumun oluştuğunu düşünmektedirler. Bununla birlikte, \% 14.3'lük (B Şıkkı) bir kesim suda kovalent bağların metanınkiler kadar güçlü olmadığını düşünmektedir. Bu akıl yürütme, atomlar arasındaki bağlar kırıldığında durumların değiştiğini ileri sürer. $\mathrm{Bu}$ düşünceye sahip öğretmen adayları bir maddenin fiziksel halinin moleküller arası kuvvetlerin büyüklüğünden kaynaklandığına dair bilgiden yoksundurlar.

\section{Termokimya}

Kimya Konuları Akıl Yürütme Testinde termokimya konusuyla alakalı olarak dört soru vardır (11., 12., 19. ve 20. sorular). Bu sorular endotermik ve ekzotermik kavramlarıyla ilgilidir.

Tablo 6.

Termokimya Konusundaki Sorulara Verilen Cevapların Sayısı ve Yüzdesi

\begin{tabular}{ccccccc}
\hline \multirow{2}{*}{ Soru } & \multicolumn{7}{c}{ Çeldiriciler-Frekans(Yüzde) } \\
\cline { 2 - 7 } & $\mathrm{A}$ & $\mathrm{B}$ & $\mathrm{C}$ & $\mathrm{D}$ & $\mathrm{E}$ & $\mathrm{F}$ \\
\hline 11 & $\mathbf{7 0 ( 3 3 . 4 ) *}$ & $64(30.5)$ & $76(36.2)$ & - & - & - \\
\hline 12 & $75(35.7)$ & $2(1.0)$ & $\mathbf{5 9}(\mathbf{2 8 . 1})^{*}$ & $5(2.4)$ & $7(3.3)$ & $62(29.5)$ \\
\hline 19 & $\mathbf{8 6 ( 4 1 . 0} *$ & $89(42.4)$ & $35(16.7)$ & - & - & - \\
\hline 20 & $31(14.8)$ & $112(53.3)$ & $\mathbf{6 7 ( 3 1 . 9} *$ & - & - & - \\
\hline
\end{tabular}

*: Doğru cevapların ortalama yüzdesi \% 29.3'dür.

Soru 11:Bu soruda bir bağ kırılması esnasında hangi olay veya olayların gerçekleştiği sorulmuştur.

Bir bağın kırılması için bağ yapan atomlar arasındaki çekim kuvvetlerinin yenilmesi amacıyla enerji gereklidir. Bu nedenle bağ kırılması olayı endotermik bir işlemdir. Açıklamalardan da anlaşılacağı üzere bu soru için doğru cevap A şıkkıdır.

Tablo 6 verileri incelendiğinde, öğretmen adaylarının \% 33.4'ünün (A Ş1kkı) bu soruya doğru yanıt verdiği görülmektedir. Bir diğer \% 36.2'lik (C Şıkkı) grup, enerji alınması veya verilmesinin şartlara (bağlı atomların tipi, bağın nasıl kırıldığı ve $T$ ve $\mathrm{P}$ gibi çevresel koşullara) bağlı olduğunu düşünmektedir. $\mathrm{Bu}$ şıkkı işaretleyen öğretmen adayları bağın kırılması sürecinin şartlara göre değişmediğini bilmemektedirler. Halbuki değişik bağların koparılması sürecindeki fark, bağı 
koparmak için gereken enerji miktarıdır. Öte yandan \% 30.5'lik (B Şıkkı) bir grup enerji yayıldığını düşünmektedir. Bu öğretmen grubu, bağların belirli bir enerjiye sahip olduğuna, bağ kırıldığı zaman ise bu enerjinin yayıldığını düşünmektedirler.

Soru 12: Bu soruda öğretmen adaylarının 11.soruya vermiş oldukları cevabın nedeni sorulmuştur.

Önceki soruda belirtildiği gibi, bağ koparmak için moleküle enerji verilmelidir. Bağın kopması, yeni bağlar oluşmadan önce bileşenlerin atomik konfigürasyonlarını geri yükler.

Tablo 6 verileri incelendiğinde, fen bilgisi öğretmeni adaylarının \% 28.1'inin (C Şıkk1) soruyu doğru cevapladığ 1 görülmektedir. Fen bilgisi öğretmeni adaylarının çoğu sağlam bir mantık yürütememiştir. Örneğin, \%35.7'lik (A şıkkı) bir oran, bağ bozulduğunda bağlarda depolanan enerjinin 1s1 olarak birakılan enerji olduğunu düşünmektedir. \% 29.5'lik (F Şıkkı) bir diğer grup reaksiyonların düşük sıcaklıkta endotermik olduğunu, ancak yüksek sıcaklıkta ekzotermik olduğunu düşünmektedir. $\mathrm{Bu}$ tür akıl yürütme, fen bilgisi öğretmeni adaylarının, tepkimeyi başlatmak için dışardan enerji verilmesinin reaksiyonun endotermik olduğu sonucuna varmak için yeterli olduğunu düşündüklerini göstermektedir.

Soru 19:Bu soru bağ enerjilerine bakılarak bir reaksiyonun endotermik mi yoksa ekzotermik mi olduğunun belirlenip belirlenemeyeceği ile alakalıdır. Soruda reaksiyona girenlerin bağ enerjilerinin toplamının ürünlerin bağ enerjilerinin toplamından küçük olması durumunda reaksiyonun ekzotermik mi yoksa endotermik mi olduğu sorulmuştur.

Kimyasal reaksiyonlarda, ürünlerin yeni bağları oluşmadan önce girenlerin molekül bağları kırılır. Bağları kırmak için enerji absorblanır, bağlar oluştuğu zaman dışarı enerji salınır. Bir bağı kırmak için gereken enerjiye bağ enerjisi denir (Silberberg, 2013). Endotermik bir işlem 1s1 absorbe eder ve sistemin entalpisinde artışa neden olur. Öte yandan, ekzotermik bir süreç 1sıyı serbest bırakır ve sistemin entalpisinde bir azalmaya neden olur. Bu durumda bağın kırılması süreci endotermik iken bağ oluşma süreci ekzotermiktir. Bağ enerjilerinin kullanılması ile sistemin entalpi değişimi şu şekilde hesap edilir: Girenlerin bă̆ enerjilerinin toplamı ile ürünlerin bağ enerjilerinin toplamı arasındaki fark hesaplanır. $\mathrm{Bu}$ fark negatif olduğunda reaksiyon ekzotermiktir, pozitif bir fark var ise reaksiyonun endotermik olduğu anlamına gelir. Böylece, bir ekzotermik reaksiyon için ürünler girenlerden daha fazla toplam bağ enerjisine sahiptir. Benzer şekilde, bir endotermik reaksiyon için, reaksiyona giren maddeler ürünlerden daha fazla toplam bağ enerjisine sahiptir. $\mathrm{Bu}$ soruda girenlerin toplam bağ enerjisinin ürünlerinkinden daha az olduğu bildirildiğinden soruda verilen reaksiyon ekzotermiktir. Yani doğru yanıt A şıkkıdır.

Tablo 6 verileri incelendiğinde, fen bilgisi öğretmeni adaylarının \% 41 'inin (A Şıkkı) bu soruyu doğru yanıtladığı görülmektedir. Bununla birlikte, öğretmen adaylarının \% 42.4’i (B Şıkkı) reaksiyonun endotermik olduğunu düşünmektedirler. 
Bu öğretmen grubu, bağ kırma enerjisinden daha fazla bağ oluşum enerjisi varsa bir reaksiyonun endotermik olduğunu düşünmektedirler.

Soru 20: Bu soruda bir reaksiyon yüksek sıcaklıklarda daha hızlı gerçekleşiyorsa reaksiyonun endotermik mi yoksa ekzotermik mi olduğu sorulmuştur.

Bir reaksiyonun meydana geldiği sicaklık, reaksiyonun ekzotermik mi yoksa endotermik mi olduğunu belirlemez. $\mathrm{Bu}$ nedenle, bu bilgiden, reaksiyonun ekzotermik veya endotermik olup olmadığı belirlenemez. Dolayısıyla doğru cevap A şıkkıdır.

Tablo 6 verileri incelendiğinde, fen bilgisi öğretmeni adaylarının \% 31.9'unun (C Şıkkı) bu soruyu doğru yanıtladığı görülmektedir. Bununla birlikte, fen bilgisi öğretmeni adaylarının çoğu (\% 53.3) reaksiyonun endotermik olduğunu düşünmektedir (B Şıkkı). Onların mantığı, yüksek sıcaklığın bağ kırma işleminin bir işareti olduğunu düşünmeleridir.

\section{Termodinamik}

Fen bilgisi öğretmeni adaylarına termodinamik ile ilgili 4 adet soru sorulmuştur (21., 22., 23. ve 34. Sorular). Bu sorular enerji transferi, spesifik 1sı kapasitesi ve entropi gibi kavramlarla ilgilidir.

Tablo 7.

Termodinamik Konusundaki Sorulara Verilen Cevapların Sayısı ve Yüzdesi

\begin{tabular}{ccccccc}
\hline \multirow{2}{*}{ Soru } & \multicolumn{7}{c}{ Çeldiriciler-Frekans(Yüzde) } \\
\cline { 2 - 7 } & $\mathrm{A}$ & $\mathrm{B}$ & $\mathrm{C}$ & $\mathrm{D}$ & $\mathrm{E}$ & $\mathrm{F}$ \\
\hline 21 & $5(2.4)$ & $14(6.7)$ & $50(23.8)$ & $\mathbf{1 3 9}(\mathbf{6 6 . 2}) *$ & $2(1.0)$ & - \\
\hline 22 & $12(5.7)$ & $82(39.0)$ & $39(18.6)$ & $\mathbf{6 6}(\mathbf{3 1 . 4}) *$ & $11(5.2)$ & - \\
\hline 23 & $\mathbf{1 1 1 ( 5 2 . 9 ) *}$ & $38(18.1)$ & $24(11.4)$ & $37(17.6)$ & - & - \\
\hline 34 & $82(39.0)$ & $\mathbf{4 9}(\mathbf{2 3 . 3}) *$ & $12(5.7)$ & $42(20.0)$ & $25(11.9)$ & - \\
\hline
\end{tabular}

*: Doğru cevapların ortalama yüzdesi \% 43.4'dür.

Soru 21: Bu soru enerji transferi ile ilgilidir. Soruda sıcaklığı $100^{\circ} \mathrm{C}$ olan 100 gramlık demir bir blok sıcaklığı $30^{\circ} \mathrm{C}$ olan 100 gramlık başka bir demir blok ile temas ettirildiğinde son durumun ne olacağı sorulmuştur.

Sistem ile çevre arasındaki sıcaklık farkının bir sonucu olarak 1sı enerjisi aktarılır (Silberberg, 2013). Bu durumda, enerji, daha yüksek bir sicaklıktaki demir bloğundan, daha düşük sıcaklıktaki demir bloğa ve çevrenin geri kalanına aktarılır. $\mathrm{Bu}$ nedenle, soğuk blok enerjiyi emer ve sicak blok enerji kaybeder, bu nedenle nihai sıcaklık başlangıç sıcaklıklarının toplamının yarısı kadardır (yanıt seçeneği D).

Tablo 7 verileri incelendiğinde, fen bilgisi öğretmeni adaylarının \% 66.2'sinin (D Şıkk1) doğru seçeneği seçtiği görülmektedir. Öğretmen adaylarının \% 23.8'lik (C Şıkkı) kısmı sıcak bloğun daha fazla enerji içerdiğinden son sicaklığın sicak bloğun sıcaklığına daha yakın olacağını düşünmüşlerdir. Öğretmen adaylarının \% 6.7'lik (B Şıkkı) kısmı sıcak bloğun daha fazla enerji içerdiğinden son sicaklığın sıcak bloğun 
Sıcaklığına eşit olacağını düşünmüşlerdir. $\mathrm{Bu}$ yanıtları işaretleyen, fen bilgisi öğretmeni adaylarının sistemin içinde ve dışında enerji akışı konusunda mantıklı bir akıl yürütmenin olmadığı anlaşılmaktadır.

Soru 22:Bu soruda soru 21 esas alınarak, demir bloklar arasında sıcaklığın dengelenmesinin nasıl meydana geldiği sorulmuştur.

Bir önceki soru için yapılan açıklamada enerjinin sıcak cisimlerden soğuk cisimlere aktığı belirtilmişti. Sıcak cisimdeki parçacıklar (örneğin atomlar) soğuk cisimlerdekilerden daha büyük bir kinetik enerjiye sahiptir. Sicaklık bir sıcak cisimden soğuk bir cisme akarken, sicak demir bloğundaki atomların kinetik enerjileri, soğuk demirdeki atomların kinetik enerjisini çarpışmalarla arttırır. Bu olay neticesinde, sicak demir bloğunun kinetik enerjisinin düşmesine ve soğuk demir bloğundaki atomların kinetik enerjisinin artmasına neden olur. Bu nedenle soruda verilen ifadelerin tamamı doğru olacak ve doğru yanıt D şıkkı olacaktır.

Tablo 7 verileri incelendiğinde, fen bilgisi öğretmeni adaylarının \% 31.4'unun (D Şıkk1) bu soruya doğru yanıt verdiği görülmektedir. Bununla birlikte,fen bilgisi öğretmeni adaylarının \% 39'u verilen ifadelerden sadece B şıkkında verilenin (Sıcak demirdeki atomların yüksek kinetik enerjisi, çarpışma nedeniyle (soğuk demir atomları ile) soğuk demirdeki atomların kinetik enerjisini arttırır) doğru olduğunu düşünmektedir. Öğretmen adaylarının \% 18.6'sı doğru ifadenin sadece C olduğunu düşünmektedir. Öğretmen adaylarının yaklaşık üçte ikisi bu soru için doğru akıl yürütmemişlerdir.

Soru 23: $\mathrm{Bu}$ soru spesifik 1sı kapasitesi ile ilgilidir. Soruda $\mathrm{X}$ ve $\mathrm{Y}$ olarak ifade edilen katıdan hangisinin spesifik 1sı kapasitesinin daha yüksek olduğu sorulmuştur. Soruda $\mathrm{X}$ ve $\mathrm{Y}$ nin aynı kütleye sahip olduğu ve aynı sıcaklıkta bulundukları belirtilmiştir. $\mathrm{X}$ ve $\mathrm{Y}$ nin her ikisi de aynı hacim ve aynı sıcaklıktaki iki ayrı su kabına konulmuştur. Sonuçta X katısının konulduğu kaptaki suyun daha sıcak olduğu belirlenmiştir. Verilen bu bilgiler 1şı̆̆ında $X$ ve $Y$ den hangisinin spesifik 1sı kapasitesinin (gram başına) daha yüksek olduğu sorulmuştur.

Bir maddenin aldığı veya verdiği ısı miktarı sıcaklıktaki değişimle orantılıdır. Bir cismin bir gramının sıcaklığını bir derece arttırmak için verilmesi gereken 1sı miktarı spesifik 1sı kapasitesi olarak adlandırılır ve her maddenin kendine özgün bir spesifik 1S1 kapasitesi vardır. Spesifik 1Sı kapasitesi düşük olan bir maddenin sıcaklığını 1 derece arttırmak için spesifik ısı kapasitesi yüksek olan başka bir maddeye göre daha az enerjiye ihtiyaç vardır. Bu soruda, $\mathrm{X}$ ve $\mathrm{Y}$ maddelerinden her biri kendi isısını suya veriyor ve bu da suyun sıcaklığının yükselmesine neden oluyor. Özgül 1sı kapasitesi daha yüksek olan madde suyun sıcaklığında daha yüksek bir değişmeye neden olur. Bu nedenle, $\mathrm{X}$ maddesinin spesifik 1sı kapasitesi Y maddesinin spesifik 1sı kapasitesinden daha büyüktür.

Tablo 7 verileri incelendiğinde, fen bilgisi öğretmeni adaylarının \% 52.9'unun (A Şıkkı) bu soruyu doğru yanıtladığı görülmektedir. Bununla birlikte, \% 18.1'i (B 
Şıkk1) Y'nin X'ten daha yüksek bir özgül 1sı kapasitesine sahip olduğunu düşünürken, \% 11.4'ü (C Şıkk1) 1sı kapasitelerinin eşit olduğunu düşünmektedir. Bu şekilde düşünen fen bilgisi öğretmeni adaylarının 1sı kapasitesi hakkında yeterli bilgiye sahip olmadığı aşikardır.

Soru 34: Bu soruda evrenin entropisinin niçin sürekli arttığı sorulmuştur.

Bir termodinamik sistemi düşünelim. Bu sistemde mekanik işe çevrilemeyecek termal enerjiyi temsil eden termodinamik terimine entropi denilir. Başka bir ifadeyle sistemdeki düzensizliktir. Düzensizlik entropi adı verilen nicelik ile ifade edilir. Sistemlerdeki düzensizlik arttıkça, entropi (faydasız enerji) de ona paralel olarak artar. Entropi, sistemin enerjisinin mümkün olan mikroskobik enerji seviyesinde dağıtılması süreciyle alakalı termodinamik bir özelliktir. Mikroskobik enerji seviyeleri hal olarak da adlandırılırlar. Haller arasında belli miktarda parçacığın dağıtıldığı özel yol mikrohal olarak adlandırılır. Entropi, mikroskobik parçacıkların konfigürasyonlarının sayısının artmasıyla artar. Sonuç olarak mikrohallerin sayısının artmasıyla entropi artar. Herhangi bir şartta, her bir mikrohal diğer mikrohaller gibi toplam bir enerji miktarına sahiptir. Bu durumda bir sistem için, her mikrohalin bulunma ihtimali eşittir. Olasılık yasalarına göre, tüm mikrohaller zamanla eşit derecede mümkün hale gelir. Bu açıklamadan, entropinin olasıllğı ölçtüğü sonucuna varılabilir. Bu nedenle, 34. Soruya en iyi cevap seçeneği B.'dir.

Tablo 7 verileri incelendiğinde, fen bilgisi öğretmeni adaylarının \% 23,3'ünün (B Şıkkı) bu soruyu doğru yanıtladığı görülmektedir. Fen bilgisi öğretmeni adaylarının çoğu, bu soruda mantıklı akıl yürütme gösterememiştir. Örneğin, \% 39'luk (A Şıkkı) bir kesim enerji tüketildiğinde entropinin arttığını düşünmektedir. Benzer şekilde, \% 20’lik (D Şıkkı) bir kesim, ısının entropi ürettiğini düşünmektedir.

\section{Sonuç ve Tartışma}

Akıl yürütme kavramı bilim literatürüne girmesiyle beraber birçok ülkenin eğitim sisteminde yer almıştır. Ülkemizde de Milli Eğitim Bakanlığı Talim ve Terbiye Kurulu'nun yayınlamış olduğu 2018 ortaokul fen bilgisi öğretim programında öğrenciye kazandırılması gereken becerilerden birinin akıl yürütme olduğu ifade edilmiştir. Akıl yürütme farklı bilimler için farklı şekillerde tanımlanmış, bu tanımlardan birisi de kimya konuları ile ilgili akıl yürütme olmuştur. Bu kavramın literatürdeki türevleri oluşmakla beraber her geçen gün önemi de artmaktadır (Baxter ve Junker, 2001; Garfield, 2002; Kesercioğlu, Yılmaz, HuyugüzelÇavaş ve Çavaş, 2004; MEB, 2018; Russell, 1999; Umay, 2003; Zieffler, Garfield, Delmas ve Reading, 2008). Bu doğrultuda çalışmada, fen bilgisi öğretmeni adaylarının kimya konularına iliş̧kin doğru ve yanlış akıl yürütmeleri araştırılmıştır.

Araştırmada fen bilgisi öğretmeni adaylarına kimyasal reaksiyonlar konusuyla alakalı dört soru yöneltilmiştir. Bu sorularda fen bilgisi öğretmeni adaylarından bir kimyasal reaksiyonun denkleştirilmesi, sınırlayıcı bileşen ve farklı kütlelerde ürün ve girenlerin olduğu reaksiyon gibi konularda akıl yürütmeleri istenmiştir. Fen 
bilgisi öğretmeni adaylarının yaklaşık yarısı kimyasal reaksiyon kavramları üzerine doğru akıl yürütmüştür. Öğretmen adaylarının akıl yürütmelerinin yüksek olduğu konular şunlardır; kimyasal reaksiyonların denkleştirilmesi, sınırlayıcı bileşen, aynı sıcaklık ve basınçta su ve oksijen molekülleri arasındaki kütle farkının nedeni ve verilen maddenin mol sayısının bilinmesinin önemi. Fen bilgisi öğretmeni adaylarının konu ile ilgili yanlış düşünceleri ise şunlardır; Moleküller bir kimyasal reaksiyonda atom olarak var olabilirler, bir reaksiyon denkleştirilirken en küçük katsayıların kullanılmasına gerek yoktur, bir reaksiyon sonlandığında sınırlayıcı bileşenden de artabilir, hidrojen oksijenden daha hafif olduğu için su daha hafiftir, fazlaca kullanılan bir reaktif bir kimyasal reaksiyonu belirleyebilir. Bunun sebebi fen bilgisi öğretmeni adaylarının genel kimya laboratuvarı dersini almış olmaları olabilir. Bu bulguya benzer şekilde Yıldız, Akpınar, Aydoğdu ve Ergin (2006) çalışmalarında deneylerle işlenen derslerin teorik ders ortamlarına göre daha kalıcı olduğu ve akıl yürütmelerinin geliştiğini tespit etmiştir. Bu sebeple araştırmacılar deney süreçleri ile akıl yürütmelerinin ilişkili olduğunu ifade etmiş̧lerdir.

Araştırmada öğretmen adaylarına uygulanan testte kinetik molekül teorisi konusuyla alakalı olarak üç soru vardır. Bu sorularda sabit basınç ve sıcaklıkta hacimleri eşit olan iki ayrı gazın mol sayıları ile ideal gazlarda hacim ve basınç arasındaki ilişki esas alınmıştır.Fen bilgisi öğretmeni adaylarının neredeyse yarısının kinetik molekül teorisi üzerinde doğru akıl yürütmesine sahip olduğu görülmektedir. Özellikle, Avogadro ve Boyle gaz kanunlarında mantıksal akıl yürütme göstermişlerdir. Bilimsel olarak doğru olmayan akıl yürütme örnekleri şunlardır: Sabit sıcaklık ve basınçta tüm gazlar ideal gaz kanununa uyarlar, sabit sicaklık ve basınçta tüm gazların hacmi aynıdır, miktarı sabit bir gazın basıncı sıcaklık da sabit tutulduğu zaman hacimle direkt olarak ters orantılıdır. Bir gazın artan basıncı hacmi artırır, çünkü basınç kabın hacmini arttırmasına neden olur. Bunun sebebi fen bilgisi öğretmeni adaylarının ilgili kimya problemlerini çözerken akıl yürütmelerini kullanmış olmalarıdır. Literatür taraması yapıldığında bu bulguyu destekleyen sonuçlara rastlamak mümkündür. Niaz (2007) çalışmasında akıl yürütme stratejilerinin kimya alanındaki problemlerin çözümünde bilişsel anlamda belirleyici olduğunu tespit etmiştir.

Çalışmada faz dengeleri konusuyla alakalı fen bilgisi öğretmeni adaylarına dört soru yöneltilmiştir. Bu sorularda fen bilgisi öğretmeni adaylarının faz dengeleri ile ilgili akıl yürütmeleri incelenmiştir.Fen bilgisi öğretmeni adaylarının neredeyse üçte biri faz değişimleri ve buhar basıncı gibi faz dengesi kavramları hakkında doğru akıl yürütmeye sahiptir. Öğretmen adaylarının çoğu, bilimsel olarak doğru olmayan akıl yürütmeler sergilemişlerdir. Bu tür yanlış akıl yürütmelere örnek olarak şunlar verilebilir: Artan sıcaklık, molekülleri iyonlara dönüştürür, basınç hacim ile ters orantılı olduğundan hacimin artması buhar basıncını düşürür. Denge halindeki kapalı bir sistem için: hacmin artmasıyla artan hacmi doldurmak için buhar basıncı artar, hacim arttıkça yoğunlaşma oranı artar. Aynı sıcaklık ve basınçta, atomlar arasındaki bağın kuvveti bir maddenin halini belirler; moleküllerin ağırlığı da maddenin halini belirler. Bunun sebebi fen bilgisi öğretmeni adaylarının kullandıkları kurallara 
dayalı akıl yürütmeleri olabilir. Literatür taraması yapıldığında bu bulguyu destekleyen çalışmalara rastlamak mümkündür. Kraft, Strickland ve Bhattacharyya (2010) öğrencilerin girişimlerinin yaklaşık üçte birinin kullandıkları kurallara dayalı akıl yürütmede oldukça etkisiz olduğunu ifade etmiştir.

Araştırmada termokimya konusuyla alakalı fen bilgisi öğretmeni adaylarına dört soru yöneltilmiştir. Bu sorular endotermik ve ekzotermik kavramlarıyla ilgilidir. Fen bilgisi öğretmeni adaylarının üçte birinden az bir kısmı, genel anlamda ekzotermik ve endotermik işlemler gibi termokimya kavramları üzerine doğru akıl yürütmeye sahiptirler. Yine fen bilgisi öğretmeni adaylarının neredeyse üçte biri bağ enerjileri hakkında bir bilgiye dayanarak bir reaksiyonun ekzotermik veya endotermik olup olmadığını doğru bir şekilde tespit edebilme yeteneğine sahiptir. Bununla birlikte fen bilgisi öğretmeni adaylarının çoğu termokimya konusunda doğru akıl yürütmeye sahip değildir. Bu konuyla ilgili bilimsel olarak doğru olmayan akıl yürütmelerine birkaç örnek şu şekilde verilebilir: Bağ kırılması esnasında enerji salınır, bir reaksiyon düşük sicaklıklarda gerçekleşiyorsa endotermiktir, yüksek sicaklıkta gerçekleşiyorsa ekzotermiktir, bir endotermik reaksiyonda, girenler ürünlerden daha fazla toplam bağ enerjisine sahiptir, bağ oluşumu endotermik iken bağ kırılması ekzotermiktir. Bunun sebebi fen bilgisi öğretmenadaylarının lisans düzeyinde almış olduğu genel kimya dersinde yapmış oldukları eğitimsel faaliyetler olarak görülebilir. Silberberg (2013) kimyasal reaksiyonlarda, ürünlerin yeni bağları oluşmadan önce girenlerin molekül bağlarının kırıldığını, bağları kırmak için enerji absorbe edildiğini, bağlar oluştuğu zaman dışarı enerji salındığını ve bir bağı kırmak için gereken enerjiye bağ enerjisi denilebileceğini ifade etmiştir. Yine Shapley (1998) yapmış olduğu çalışmasında öğretim süreci sonucunda öğrencilerin kimya ile ilgili karmaşık akıl yürütmeleri kazandıkları tespit edilmiştir.

Çalışmada fen bilgisi öğretmeni adaylarına termodinamik ile ilgili 4 adet soru sorulmuştur. $\mathrm{Bu}$ sorular enerji transferi, spesifik 1sı kapasitesi ve entropi gibi kavramlarla ilgilidir. Genel anlamda, fen bilgisi öğretmeni adaylarının yarıya yakınının termodinamik kavramları üzerine doğru akıl yürütmeye sahip olduğunu söylemek mümkündür. Özellikle, fen bilgisi öğretmeni adaylarının, evrenin enerji transferi, özgül 1sı kapasitesi ve entropisi hakkında doğru akıl yürüttüğü söylenebilir. Öğretmenlerin neredeyse yarısının mantığı bilimsel olarak doğru değildir. Bilimsel olarak doğru olmayan akıl yürütmeleri şöyledir: Sicak bir nesneden soğuk bir nesneye akar ve her iki cismi de daha düşük bir sıcaklığa getirir; aynı kütle ve sıcaklıktaki farklı maddeler aynı özgül 1sı kapasitesine sahiptir, enerji tüketildiğinde entropi de artar. Bunun sebebi fen bilgisi öğretmeni adaylarının akıl yürütme yönünden yeterli beceriye sahip olmamaları olarak görülebilir. Literatür taraması yapıldığında benzer sonuçlar elde eden çalışmalara rastlamak mümkündür. Berker ve Millar (2010) çalışmalarında, öğrencilerin yaklaşık yarısının doğru akıl yürütmelerini gösterdiklerini ifade etmişlerdir. Ayrıca McClary ve Talanquer (2010) çalışmalarında öğrencilerin akıl yürütme stratejilerinin karakterizasyonu, anlamlı öğrenmeyi teşvik eden öğretim stratejilerinin geliştirilmesinde merkezi bir öneme sahip olduğunu dile getirmişlerdir. 
Sonuç olarak fen bilgisi öğretmeni adaylarının kimyasal reaksiyonlar, kinetik molekül teorisi, faz dengeleri, termokimya ve termodinamik konularında ortalamanın altında veya ortalamaya yakın bir akıl yürütmeye sahip oldukları ve bu konu alanı ile ilgili hatalı akıl yürütmelerine sahip oldukları görülmektedir. $\mathrm{Bu}$ doğrultuda ilgili alanda çalışmak isteyen araştırmacılara şu önerilerde bulunulmuştur;

1. Mevcut çalışma fen bilgisi öğretmeni adaylarının kimya konularındaki akıl yürütmelerini araştırmak amacıyla yapılmıştır. Benzer şekilde kimya öğretmenlerinin kimya konularındaki akıl yürütmeleri araştırılabilir veya fen bilgisi öğretmeni adaylarıyla akıl yürütme becerileri karşılaştırılabilir.

2. Daha büyük kitleler üzerinde (birden fazla üniversitede okuyan öğretmen adayları örneklem olarak seçilecek şekilde) yeni araştırmalar yapılabilir.

3. Üniversitelerin lisans programlarına araştırma kapsamına alınan veya diğer kimya konuları üzerine akıl yürütmelerini içeren seçmeli dersler eklenebilir.

\section{Kaynakça}

Aladağ, A. \&Artut, P.D. (2012). Öğrencilerin orantısal akıl yürütme ve gerçekçi problem çözme becerilerinin incelenmesi. Ilköğretim Online, 11(4), 9951010.

Apaydın, Z. \& Taş, E. (2010). Farklı etkinlik tiplerinin öğretmen adaylarının akıl yürütme becerileri üzerindeki etkileri. Türk Fen Eğitimi Dergisi, 7(4), 174191.

Ayas, T. \& Horzum, M.B. (2012). On being cyberbully and victim among primary school students. Elementary Education Online, 11(2), 369-380.

Azizoğlu, N., Alkan, M. \& Geban, O. (2006). Undergraduate pre-service teachers' understandings and misconceptions of phase equilibrium. Journal of Chemical Education, 83(6), 947-953.

Banda, A. (2012). Zambian pre-service junıor high school sclence teachers' chemical reasoning and ability (Publishing Doctoral Thesis), M.S.,Southern Illinois University, Zurih.

Bao, L.,Cai, T., Koeing, K., Fang, K., Han, J., Wang, J., Liu, Q., Ding, L., Cui, L., Luo, Y., Wang, Y., Li, L. \& Wu, N. (2009). Learning and scientific reasoning.Journal ofScience, 586 (2009), 1-9.

Berker V. \& Millar R. (2010). Students' reasoning about basic chemical thermodynamics and chemical bonding: what changes occurduring a contextbased post-16 chemistry course? International Journal of Science Education, 22(11), 1170-1200.

Baxter G.P. \& Junker, B.A. (2001). Case study in proportional reasoning. Paper presented at the annual meeting of the National Council for Measurement in Education Seattle (NCMES), Journal of Washington. 2(3). 31-40.

Büyüköztürk, Ş., Çakmak, E., Akgün, Ö.E., Karadeniz Ş. ve Demirel, F. (2012). Bilimsel Araştırma Yöntemleri. Pegem Akademi Yayıncılık, Ankara. 
Çalık, M.,Ayas, A. \&Coll, R.K. (2010). Investigating the effectiveness of usage of differentmethodsembedded with four-step constructivistteachingstrategy. Journal of Science Education and Technology, 19(1), 32-48.

Çelik, A. \&Özdemir, E. Y. (2011). İlköğretim öğrencilerinin orantısal akıl yürütme becerileri ile problem kurma becerileri arasındaki ilişki. Pamukkale Üniversitesi Eğitim Fakültesi Dergisi, 30(30), 1-11.

Cavallo, A.M.L. (1996). Meaningfullearning, reasoning ability and students' Understanding and problem solving of topics in genetics. Journal of Research in Science Teaching, 33(6), 625 - 656.

Cloonan, C.A. \& Hutchinson, J.W. (2011). A chemistryconcept reasoning test. Chemistry Education Research and Practice, 12(1), 205-209.

Çetin, P.S.,Erdurhan, S. \&Kaya, E. (2010). Kimyanın doğası ve argümantasyonu anlama: kimya öğretmen adayları ile bir durum çalışması.Ahi Evran Üniversitesi, Kırşehir Eğitim Fakültesi Dergisi, 11(4), 41-59.

Fraenkel, J.R. \&Wallen, N.E. (2006). How to design and evaluateresearch in education (6th ed.). New York, NY: McGraw-Hill.

Furr, R.M. \& Bacharach, V.R. (2008). Psychometrics: An introduction. ThousandOaks, CA:Sage.

Garfield, J. (2002). Te Challenge of developingstatistical reasoning. Journal of Statistics Education, 10(3). 123-135.

Gravetter, F.J. \&Forzano, L.B. (2006). Research methods for the behaviouralsciences (2nd ed.).Belmont, CA: ThomsonWadsworth.

Haidar, A.H. (1997). Prospectivechemistryteachers' conceptions of the conservation of matter and relatedconcepts. Journal of Research in Science Teaching, 34(2), 181-197.

Kesercioğlu, T., Yılmaz, H., HuyugüzelÇavaş, P. \&Çavaş, B. (2004). İlköğretim fen bilgisi öğretiminde analojilerin kullanımı: “örnek uygulamalar”.Ege Ĕ̈itim Dergisi, 5(1), 35-44.

Koeing, K. Schen, M. \&Bao, L. (2012). Explicitly targetingpre-service teacher scientific reasoning abilities and understanding of nature of science through an introductory science course. National Science Teachers Association, 21(2), 1-9.

Kraft, A. Strickland A.M. \& Bhattacharyya, G. (2010). Reasonable reasoning: multivariate problem-solving in organic chemistry.Chemistry Education Research and Practice, 4(11), 281-292.

Kurtz, K.J.,Gentner, D. \&Gunn, V. (1999). Reasoning. In B.M. Bly ve D.E. Rumelhart (Eds.), Handbook of perception and cognition (2nd ed.). Cognitive science (pp. 145-200).

Leedy, P. \& Ormrod, J. (2001). Practicalresearch: Planning and design (7th ed.). Upper SaddleRiver, NJ: Merrill PrenticeHall. ThousandOaks: SAGE Publications.

MEB (2018). Illkokul ve ortaokul fen bilgisi dersi 1-8. sinıflar ögretim programı. Ankara. Talim ve Terbiye Kurulu Başkanlığı.

Metin, M. (2012). Investigation of primary students' opinions about usingperformanceassessment in Science and technologycourse with respect to 
the differentvariables. Asia-Pacific Forum on Science Learning and Teaching, 13(2), 7-8.

McClary L. \&Talanquer V. (2010).Heuristicreasoning in chemistry: makingdecisions about acidstrength.International Journal of Science Education 33(10), 1433-1454.

Niaz M. (2007). Reasoning strategies of students in solvingchemistryproblems as a function of developmentallevel, functional M-capacity and disembeddingability.International Journal of Science Education, 10(2), 525541.

Oaksford, M. (2005). Reasoning. In Nick Braisby ve Angus Gellatly, Cognitivepsychology, pp. 418-457. New York: Oxford University PressInc.

Özkaya, A. R., Uce, M. \& Sahin, M. (2003). Prospectiveteachers' conceptualunderstandingofelectrochemistry: Galvanic and electrolyticcells. University Chemistry Education, 7(1), 1 -12.

Pehlivan, K.B. (2010). Öğretmen adaylarının öğrenme stilleri ve öğretmenlik mesleğine yönelik tutumları üzerine bir çalışma. İlköğretim Online, 9(2). 123.

Petrucci, R.H.,Harwood, W.S. \&Herring, F.J. (2002). Química General. PrenticeHall, Spain.

Russell, S.J. (1999). Mathematical reasoning in the elementarygrades. In Lee V. Stiff (Ed.), Developingmathematical reasoning in grades K-12/1999 yearbook. Reston, Virginia: National Council of Teachers of Mathematics. 2(4). 455-488.

Sandur, G.,Özbayrak, O. \& Uyulgan, M. (2011). A study of determination of preservice chemistryteachers' understanding about acids and bases. Procedia Computer Science, 3(1), 52 - 56.

Shapley P. (1998). On-lineeducation to developcomplex reasoning skills in organicchemistry.University of Illinois at Urbana-Champaign, 845(1), 45-52.

Silberberg, M.S. (2013). Principles of general chemistry, (3rd ed.). New York, NY: McGraw-Hill.

Storey, S.O. (2004). Teacherquestioning to improveearlychildhood reasoning.Publishing Doctoral Thesis, The University of Arizona. Available from ProQuest Dissertations and Theses database. (UMI Microform 3132260).

Tekin, S. \&Ayas, A. (2002). Ortaöğretimde kimya dersi alan öğrencilerin hazırladıkları kimya sorularının değerlendirilmesi.Karadeniz Teknik Üniversitesi Fatih Ĕ̈itim Fakültesi Dergisi, 2(3). 1-5.

Tok, Ş. (2008). The effects of reflectivethinkingactivities in science course on academicachievements and attitudes toward science.Elementary Education Online, 7(3), 557-568,

Tümkaya, S. (2011). Fen bilimleri öğrencilerinin eleştirel düşünme eğilimleri ve öğrenme stillerinin incelenmesi.Ahi Evran Üniversitesi Eğitim Fakültesi Dergisi, 12(3), 215-234.

Umay, A. (2003). Matematiksel muhakeme yeteneği. Hacettepe Üniversitesi Ĕ̆itim Fakültesi Dergisi, 24(1), 234-243. 
Valanides, N. (2000). Primary studentteachers' understanding of the particulate nature of matter and itstransformationsduringdissolving. Chemistry Education: Research and Practice in Europe, 1(2), 249-262.

Yıldırım, C. (1966). Eğitimde Araştırma Metotları. Ankara: Akyıldız Yayınevi.

Yıldız, E., Akpınar, E., Aydoğdu, B. \& Ergin Ö. (2006). Fen bilgisi öğretmenlerinin fen deneylerinin amaçlarına yönelik tutumları. Türk Fen Eğitimi Dergisi, 3(2). 2-16.

Zieffler, A., Garfield, J., Delmas, R. \&Reading, C. (2008). A framework to supportresearch on informalinferential reasoning.Statistics Education Research Journal, 7(2), 40-58.

Zumdahl, S.S. \&Zumdahl, S.A. (2010). Chemistry, (8th ed.). Belmont, CA: BrooksCole.

\section{Extended Abstract}

With the development process of science, the concept of reasoning has emerged and works have been done with each passing day. In this development process, the concept of reasoning has been tried to be defined by many scientists. Kurtz, Genter and Gunn (1999) on reasoning are as follows; Reasoning can be defined as a cognitive process in which people take knowledge and make an implication according to the data. According to Umay's (2003) definition; The process of thinking and taking a rational conclusion considering all factors "; The thinking process is the ability to derive meaning from events and reorganize the conditions accordingly" (Umay, 2003). The most important thing expected from chemistry teachers is that they convert chemistry knowledge into effective educational practice. A chemistry teacher who can make effective educational practices should also have a high level of chemistry ability and chemistry ability. There are many studies on the understanding of chemistry subjects of science teachers in literature. For example, the level of understanding of acids and bases, the structure of matter, phase equilibrium, electrochemistry and solution chemistry were investigated in detail by different research groups (Sandur, Ozbayrak, and Uyulgan, 2011; Valanides, 2000; Azizoglu, Alkan, and Geban). , 2006). In these studies, it was concluded that general science teacher candidates had low level of understanding of the chemistry subjects. The aim of this study is to examine the reasoning of science teacher candidates on chemical reactions, kinetic molecular theory, phase equilibrium, thermo chemistry and thermo dynamics. Since the study included numerical data, it was carried out according to the survey model of quantitative research methods. Survey models are the arrangements made over the whole universe or a sample taken from it in order to make a general judgment about the whole of the universe in a universe consisting of a large number of participants (Karasar, 1995). The universe of this study consists of the students studying in the department of Science Education in the Faculty of Education of Firat University in the spring of 2016-2017. The sample of the study consists of 210 (180 Female, 30 Male) science teacher candidates selected from the related department. While the 
pre-service teachers were placed in the related section, the numerical scores of the central exam by the Student Selection and Placement Center were taken into consideration. Therefore, science teachers who prefer this section come from the numerical (Mathematics-Physics-Chemistry-Biology) departments of the high schools they are interested in. In the study, chemical reactions, kinetic molecule theory, phase equilibrium, thermo chemistry and thermodynamics sections of the Chemistry Subjects Reasoning Test developed by Cloonan and Hutchinson (2011) wereused as data collection tools. A demographic information form was also used to collect some demographic information from prospective science teachers. In the demographic information form, pre-service teachers have independent variables such as classroom, gender and graduated high school type. The tests were applied to the pre-service teachers in the 1st, 2nd, 3rd and 4th grades of the Science Teaching Program of the Faculty of Education at Firat University at the end of 2016-2017 spring semester. In the study, a total of 219 participants werere ached and 9 of these participants were not included in the study because they had in corrector in complete markings in the test applications, and the answers of the remaining 210 participants to the test were evaluated. The teacher candidates were given 1 hour to answer the questions in the test. It was concluded that this period was sufficient due to the lack of additional time from teacher candidates. During the application of the test, the researchers made the necessary explanations about the issues that the participants did not understand or wanted to explain. In addition, periodic table was distributed to the participants to look at the atomic numbers of the elements in the test. The data obtained as a result of the study applications were analyzed by using SPSS 23.00 packet program. In the research, descriptive statistics and the true-false ratios of the prospective teachers about the subject of chemistry subjects were investigated. In this direction, the right and wrong reasoning of science teacher candidates about phase equilibrium, thermochemistry and thermodynamics concepts were examined. As a result, it is seen that science teacher candidates have a reasoning under the average about chemical reactions, kinetic molecular theory, phase equilibrium, thermochemistry and thermodynamics and they have faulty reasoning about this subject area. Accordingly, the following recommendations were made to the researchers who want to work in the relevant field;

1. The present study was carried out to investigate the reasoning of science teachers on chemistry. Similarly, the reasoning of chemistry teachers in chemistry subjects can be investigated, or science teachers can compare their reasoning skills.

2. New research can be carried out on larger masses (as teacher candidates studying in more than one university).

3. Elective courses can be added to the undergraduate programs of the universities, which are included in the research or include reasoning on other chemistry subjects. 